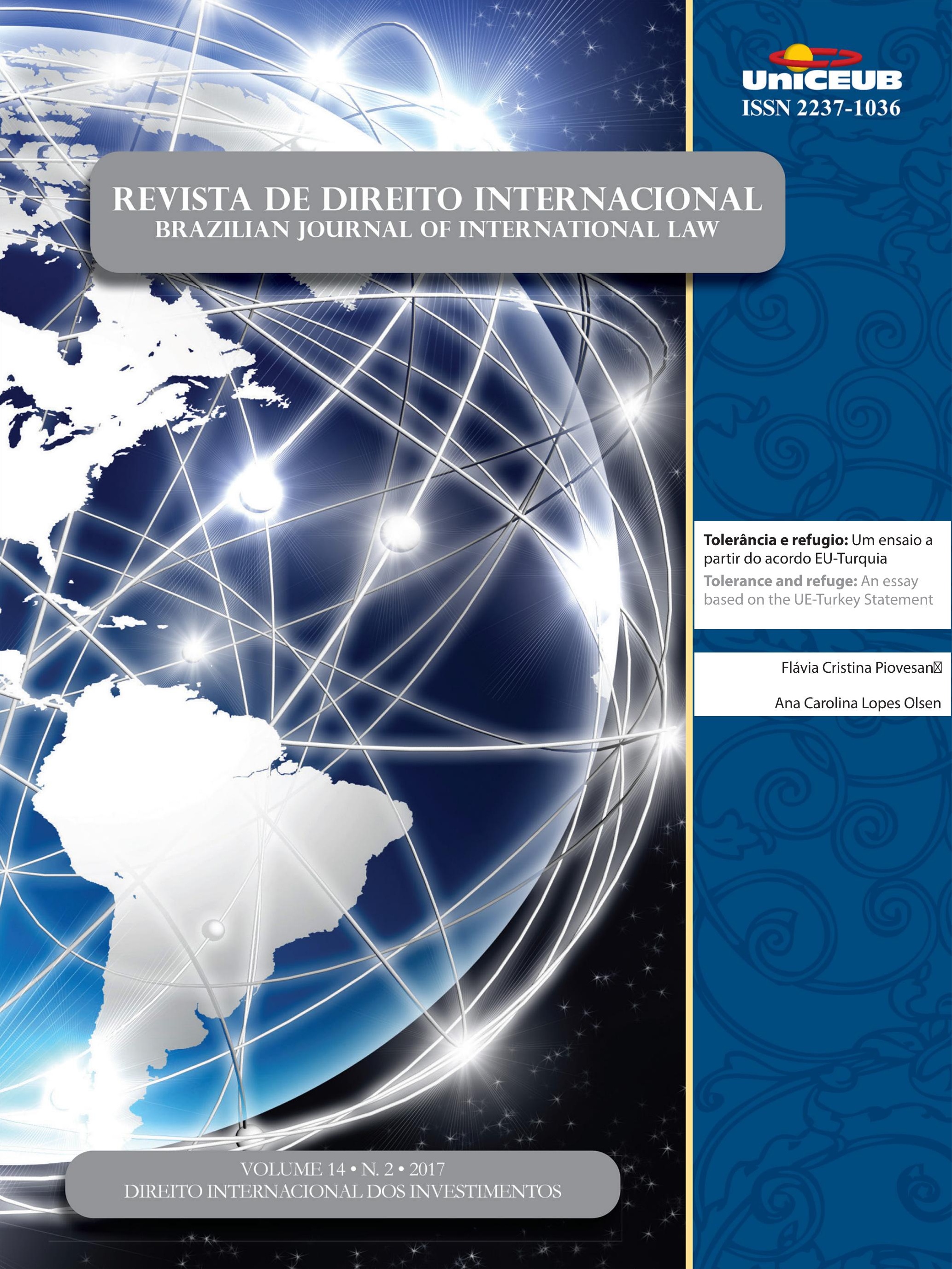




\section{Sumário}

I. Crônicas do Direito Internacional ...............................................1

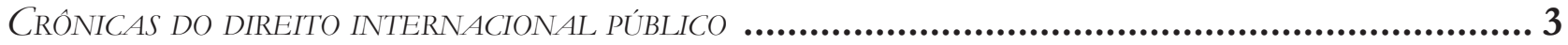

A resolução 2272 (2016) do Conselho de Segurança das Nações Unidas - O POSICIONAMENTO DA ONU FACE ÀS ALEGAÇÕES DE ABUSO E EXPLORAÇÃo SEXUAL POR SUAS

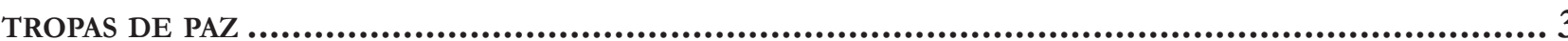

Sarah Dayanna Lacerda Martins Lima

CRÓNICAS DE DiREITo INTERNACIONAL PRIVADO...................................................................

Nadia de Araujo, Marcelo De Nardi, Gustavo Ribeiro, Fabrício Polido e Inez Lopes

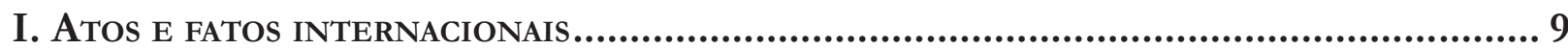

Crônica 1. Novidades de 2017 SObRE CIRCulaÇÃo faCilitada DE SENTENÇAS ESTRANGEIRAS 9

Crônica 2: O Direito Transnacional e os episódios das Carnes.........................................16

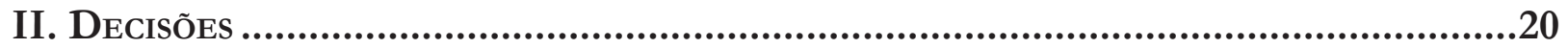

Crônica 3: A Irresistível ForÇa da ORDEM PÚblica E A HOMOLOGaÇÃo DE SENTENÇAS

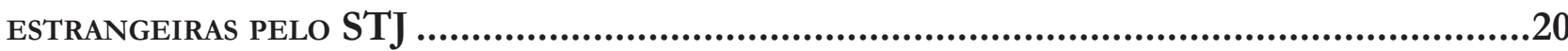

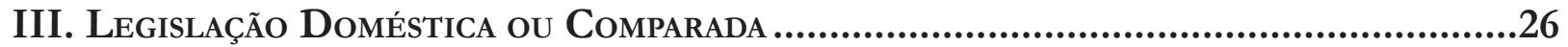

Crônica 4 - Dignidade da pessoa humana e mudança de paradigma da Lei de Migração

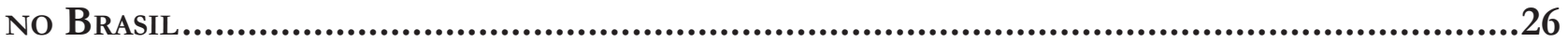

II. Dossiê especial: Direito Internacional dos InVEstimentos ................35

Non-adjudicatory State-State Mechanisms in Investment Dispute Prevention and Dispute Settlement: Joint Interpretations, Filters and Focal Points 
Mapping the Duties of Private Companies in International Investment Law .50 Nitish Monebhurrun

LA LÉGALITÉ DE L'INVESTISSEMENT DEVANT L'ARBITRE INTERNATIONAL: À LA RECHERCHE D'UN POINT D'ÉQUILIBRE .73 Hervé Ascensio

Host STATES AND STATE-STATE INVESTMENT ARBITRATION: STRATEGIES AND CHALlENGES......81 Murilo Otávio Lubamdo de Melo

Right to Regulate, Margin of Appreciation and Proportionality: Current Status in Investment Arbitration in Light of Philip Morris V. Uruguay. .95 Giovanni Zarra

Investments on Disputed Territory: Indispensable Parties and Indispensable Issues....122 Peter Tzeng

The Influence of General Exceptions on the Interpretation of National

Treatment in INTERNATIONAL INVESTMENT LAW. 140 Louis-Marie Chauvel

UMA PRoposta de REFleXão SObRe os ACFIs: Até QUE PONTO O TRATAMENTo de NAÇão MAIS FAVORECIDA PODE MINAR A ESTRATÉGIA POLÍTICA QUE OS EMBASA? 160

Michelle Ratton Sanchez Badin, Daniel Tavela Luis e Mario Alfredo de Oliveira

ECUADOR's 2017 TERMINATION OF TREATIES: HOW NOT TO EXIT THE INTERNATIONAL INVESTMENT REGIME 179

Jose Gustavo Prieto Muñoz

ONE BELT, ONE ROAD: NOVAS INTERFACES ENTRE O COMÉRCIO E OS INVESTIMENTOS INTERNACIONAIS 193

Flávio Marcelo Rodrigues Bruno e Marilda Rosado de Sá Ribeiro

III. Artigos Sobre outros TEMAS..................................................... 214

TolerânCIA E REFugIO: UM ENSAIO A PARTIR Do ACORdo EU-TurQUiA 216 Flávia Cristina Piovesan e Ana Carolina Lopes Olsen 
O TRATAMENTO do APÁtridA NA NOVA LEI DE MIGRAÇÃo: ENTRE AVANÇOS E RETROCESSOS...237 Jahyr-Philippe Bichara

O caráter humanista da Lei de Migrações: aVAnços da Lei N. 13.445/2017 E Os desafios DA REGULAMENTAÇÃO. 254 Marcelo Dias Varella, Clarice G. Oliveira, Mariana S.C. Oliveira e Adriana P. Ligiero

Reform of the United Nations Security Council: The Emperor Has No Clothes.268 Ljubo Runjic

A IDEIA DE QUe os LATINO-AMERICANOS PREFEREM O AUTORITARISMO À DEMOCRACIA À luz da reinterpretação dos Critérios do Programa das Nações Unidas para o DesenVolvimento 286

Gina Marcilio Pompeu e Ana Araújo Ximenes Teixeira

A PRoteção da ORIENTAÇÃo SEXUAL E IDENTIDAdE DE GÊNERO DIVERSAS NA CORTE PENAL internacional: Entre Realpolitiks E Os Direitos Humanos

Gustavo Bussmann Ferreira

A desnacionalização e as violações de direitos humanos na República Dominicana. 331 Daniela Menengoti Gonçalves Ribeiro e Rodrigo Ichikawa Claro Silva

CompetênCia do TPI no Caso do ATAque ao hospital de Kunduz: uma análise ENVOLVENDO A JURISDiÇÃo do TPI EM RELAÇÃO A NACIONAIS DE EsTAdOS NÃO-PARTE do Estatuto DE Roma

Filipe Augusto Silva e Renata Mantovani de Lima

A CRIMINALIZAÇÃo DOS IMIGRANTES EM SITUAÇÃo IRREGULAR NA ITÁliA: BIOPOLÍtica E DIREITO PENAL DO AUTOR.

Maiquel Angelo Dezordi Wermuth e Jeannine Tonetto de Aguiar

The New Rules On Trade And Environment Linkage In Preferential Trade Agreements

Alberto do Amaral Júnior e Alebe Linhares Mesquita

Beyond THE Border between the North and the South: towards a Decolonization of EPISTEMOLOGIES AND FIELDS OF RESEARCH ON MERCOSUR 
A aplicabilidade da Convenção de Montreal no direito brasileiro.

Aziz Tuffi Saliba e Alexandre Rodrigues de Souza

REgIME DE TRANSPARÊNCIA FISCAL NA TRIBUTAÇÃo DOS LUCROS AUFERIDOS NO EXTERIOR (CFC RULES): LACUNAS E CONFLITOS NO DIREITO BRASILEIRO

Paulo Rosenblatt e Rodrigo Torres Pimenta Cabral

As Regras Brasileiras de Tributação de Controladas e Coligadas no Exterior: verdadeiras Controlled Foreign Company (CFC) Rules? .......................................465

Melina de Souza Rocha Lukic e Amanda Almeida Muniz

O RETORNO DE BENS CULTURAIS

Aziz Saliba e Alice Lopes Fabris

Direitos culturais e Nações Unidas: uma análise a partir da Declaração Sobre a eliminação de Todas as Formas de Intolerância e Discriminação Baseadas na Religião OU NA CRENÇA

Leilane Serratine Grubba e Márcio Ricardo Staffen

OS REFLEXOS DA PROTEÇÃO INTERNACIONAL DA PROPRIEDADE INTELECTUAL PARA O DESENVOLVIMENTO INTERNO: UMA ANÁLISE SOBRE O SISTEMA PATENTÁRIO BRASILEIRO E A TRANSFERÊNCIA DE TECNOLOGIA

Michele M. Segala e Isabel Christine S. De Gregori

O CASO HIPOTÉTICO DA MORTE DO EMBAIXADOR FRANCÊS NA ESPANHA: DUAS ESPÉCIES DE IUS gentium em Francisco de Vitoria

Rafael Zelesco Barretto

De volta À BeVilaqua: anÁlise ECONÔMICA dA APLICAÇão do ART. $9^{\circ}$ DA LINDB Às OBRIGAÇÕES CIVIS CONTRATUAIS

Danielle Cristina Lanius e Ivo Teixeira Gico Jr 


\title{
Tolerância e refugio: Um ensaio a partir do acordo EU-Turquia*
}

\section{Tolerance and refuge: An essay based on the UE-Turkey Statement}

\author{
Flávia Cristina Piovesan** \\ Ana Carolina Lopes Olsen***
}

\section{Resumo}

O direito internacional dos refugiados, pós II Guerra Mundial, fundamentou-se na noção de "direito a ter direitos", de uma sociedade aberta para a diversidade e o pluralismo, com base na tolerância e na alteridade. Estas concepções estão em xeque com as recentes práticas adotadas pela União Europeia face aos refugiados, notadamente no Acordo União Europeia-Turquia (2016), que prevê a possibilidade de devolução de refugiados aos seus locais de origem, apesar do princípio do non-refoulement. A partir de pesquisa bibliográfica, e pelo método indutivo, o presente artigo busca compreender as implicações filosóficas e éticas da rejeição manifestada pela Europa ao grande contingente de refugiados de origem muçulmana, cuja cultura contrasta profundamente com os valores nutridos pelos povos europeus, a fim de sugerir uma nova compreensão da própria ideia de tolerância enquanto fundamento do Direito Internacional dos Refugiados, e mesmo dos direitos humanos. Conclui-se nesse ensaio que mecanismos burocráticos e jurídicos têm sido utilizados como máscara para a intolerância da Europa frente aos refugiados. Desse modo, a partir de contribuições teóricas de Rorty, Appiah, Heller e Ferénc, percebeu-se que somente a partir da superação da noção abstrata de tolerância, para uma compreensão cosmopolita que reconhece as pessoas em sua concretude histórica e social, bem como pelo alargamento da ideia de "nós" para enfrentar a dicotomia "nós-eles", que se pode fundamentar o direito de toda pessoa de ser acolhida, quando enfrenta o risco de sua própria aniquilação.

Palavras-chave: Refugiados; Direitos Humanos; Xenofobia; Tolerância; Europa.

\section{Abstract}

The Refugees International Law, created after the II World War, has been founded upon the idea of "a right to have rights", and a society open to diversity and pluralism, based on tolerance and alterity. The recent practices adopted by the European Union challenge these conceptions, notably the EU-Turkey Statement (2016), which prescribes the possibility of returning refugees to their origin or latest place of departure, despite of the "non-refoulement" principle. Using bibliographical research, by the inductive method, this 
article aims to understand the philosophical and ethical implications of the rejection of a great amount of muslin refugees by Europe, since their culture contrasts deeply with the values nourished by European peoples, in order to suggest a new comprehension of the ideal of tolerance as a bedrock to the Refugees International Law, and even to Human Rights Law. It concludes that legal and bureaucratic methods have been used as a mask to hide European intolerance towards refugees. Therefore, based on the contribution of Rorty, Appiah, Heller and Ferénc, it verified that tolerance can only be a keystone to the right to pledge refuge when understood in a cosmopolitan way, in which a person is seen in his historical concrete and social being, as well as the conception of "us" is enlarged, to face the dichotomy of "us-them".

Keywords: Refugees; Human Rights; Xenophobia; Tolerance; Europe.

\section{INTRODUÇão}

A preocupação jurídica com o deslocamento de pessoas forçadas a deixar seus países de origem ganhou corpo ao final da II Guerra Mundial. A Europa havia sido devastada pelos anos de conflito, e milhões de pessoas tinham deixado seus lares, sem poder regressar. Mas dessa vez, não apenas em função do conflito, como a história já havia testemunhado. Muitos europeus, e dentre eles um grande número de judeus, perderam sua nacionalidade, seu lar, em função de políticas estatais. Hitler e Stalin juntos promoveram o deslocamento de aproximadamente trinta milhões de pessoas entre 1939 e $1943 .{ }^{1}$

Havia poucos anos a Europa já havia sofrido com deslocamentos em outro grande conflito, a I Guerra, a qual deixara cem milhões de refugiados, dentre eles apátridas. Viviam à margem da sociedade, sem nenhum governo ou Estado que interviesse em seu favor. Estavam protegidos apenas pelo Tratado das Minorias ${ }^{2}$

\footnotetext{
1 "This was something new in the European experience. All wars dislocate the lives of noncombatants: by destroying their land and their homes, by disrupting communications, by enlisting and killing busbands, fathers, sons. But in World War Two it was state policies rather than armed conflit that did the worst damage". JUDT, Tony. Postwar: A Historty of Europe Since 1945. New York: Penguin Books, 2005, p. 22-23.

2 Segundo Hannah Arendt, "Os Tratados aglutinaram vários povos num só Estado, outorgaram a alguns o status de "povos estatais"
}

que foi assinado por países europeus imediatamente após a I Guerra Mundial, sem nenhuma intenção real de obediência. Para essas pessoas, a expressão "direitos humanos" prevista no Tratado representava um ato de hipocrisia. $^{3}$

Essa situação denunciou a falha ética de um sistema jurídico que admitia a existência de pessoas desapossadas do conceito de identidade nacional, privando-as de qualquer direito, bem como a total impotência da Liga das Nações em promover uma solução. Um sistema que gerava mais do que a violência, promovia o não reconhecimento do outro, sua estigmatização em uma categoria de indesejáveis. Como coloca Hannah Arendt, eram o "refugo da terra". ${ }^{4}$

Reconhecendo a insustentabilidade desse modelo, os Estados elaboraram um novo paradigma jurídico que deveria guiar os povos estabelecendo um mínimo ético irredutível: o ser humano como sujeito de direitos. Como observa Arendt, como não havia qualquer lugar «incivilizado» na terra, a humanidade precisaria aprender a conviver em um Mundo Único. Esses direitos perdidos, e a dignidade humana que eles outorgam, deveriam prevalecer independentemente de vinculação jurídica do sujeito a uma comunidade. ${ }^{5}$

e lhes confiaram o governo, supuseram silenciosamente que os outros povos nacionalmente compactos [...] chegassem a ser parceiros no governo, o que naturalmente não aconteceu, e, com igual arbitrariedade, criaram com os povos que sobraram um terceiro grupo de nacionalidades chamadas minorias, acrescentando assim aos muitos encargos dos novos Estados o problema de observar regulamentos especiais, impostos de fora, para uma parte de sua população. Como resultado, os povos não agraciados com Estados, fossem "minorias nacionais" ou "nacionalidades", consideraram os Tratados um jogo arbitrário que dava poder a uns, colocando em servidão os outros. Os Estados recém-criados, por sua vez, que haviam recebido a independência com a promessa de plena soberania nacional, acatada em igualdade de condições com as nações ocidentais, olhavam os Tratados das Minorias como óbvia quebra de promessa e, como prova de discriminação, uma vez que somente os novos Estados, e nem mesmo a Alemanha derrotada [com exceção do território da Silésia oriental, dividida em 1920 com a Polônia em decorrência de plebiscito], ficavam subordinados a eles. ARENDT, Hannah. As origens do totalitarismo. Trad. Roberto Raposo. São Paulo: 2012, p. 302-303.

3 Afinal, os direitos criados pela revolução francesa haviam sido atrelados à condição da soberania nacional dos Estados, e o Tratado das Minorias instituído pela Liga das Nações não inspirava confiança porque era a própria Liga formada por Estados soberanos, não dispostos a abrir mão de sua soberania. ARENDT, H. As origens do totalitarismo. Trad. Roberto Raposo. São Paulo: 2012, p. 302303; 305.

4 ARENDT, H. As origens do totalitarismo. Trad. Roberto Raposo. São Paulo: 2012, p. 300.

5 ARENDT, H. As origens do totalitarismo. Trad. Roberto Ra- 
Diante dessa perspectiva, erigiu-se o Direito Internacional dos Refugiados, que procura reconhecer as necessidades prementes daqueles que se veem obrigados a deixar seu país com medo da morte, da tortura, da prisão. De matriz europeia, ele reconhece a todos que se encontram nessas condições o direito de solicitar asilo.

Todavia, em um mundo já pequeno em que todos precisam conviver, os grandes contingentes de refugiados sírios que batem à portas da Europa especialmente nos últimos anos, fugindo da Guerra Civil na qual mergulhou seu país desde 2011, colocou os próprios fundamentos básicos dos Direitos dos Refugiados em cheque, como a tolerância. No lugar de respeito e acolhimento, refugiados sírios passam a ser devolvidos à Turquia em função de um Acordo por ela firmado com a União Europeia em março de 2016.

Mediante pesquisa bibliográfica e pelo método indutivo, o presente artigo procura, numa primeira parte, investigar a tolerância como fundamento básico do Direito dos Refugiados, e dos direitos humanos, em sua matriz original universal. Num segundo ponto, analisa especificamente o Acordo UE-Turquia em suas principais determinações, e suas implicações para os refugiados sírios que chegam ao território europeu. Em uma terceira parte, procura-se demonstrar que o Acordo é uma evidência da intolerância com a qual a Europa tem tratado o problema dos refugiados, agindo com base no preconceito, no racismo e na xenofobia. Finalmente, na quarta e última parte, procura-se oferecer propostas de remodelação da própria noção de tolerância, a partir das lições do cosmopolitismo, e de visões teóricas que procuram enxergar, em cada ser humano, uma pessoa histórica e concreta.

\section{TOLERÂNCIA COMO FUNDAMENTO DO DIREITO INTERNACIONAL DOS REFUGIADOS}

Passados apenas três anos da criação da Organização das Nações Unidas, foi promulgada a Declaração Universal dos Direitos Humanos, instituindo uma nova era para o Direito Internacional. Com pretensão de aplicabilidade a toda a espécie humana, independentemente de vínculo jurídico qualquer que fosse, a Declaração Universal instituía que todos deveriam ser considerados

poso. São Paulo: 2012, p. 331. iguais em dignidade e direitos, inaugurando a concepção contemporânea dos direitos humanos, cuja tônica é a recuperação do ser humano como valor fonte dos sistemas jurídicos, a ser valorizado em si a partir da concepção kantiana de que cada um é um fim em si mesmo, e a possibilidade de flexibilização da soberania dos Estados a fim de proteger os direitos da pessoa humana. ${ }^{6}$

Em seu artigo XIV, a Declaração Universal reconheceu o direito de pedir asilo a todos aqueles que fossem vítimas de perseguição. Essa foi a premissa jurídica para a elaboração, e promulgação em 1951, da Convenção de Genebra sobre o Estatuto dos Refugiados, seguida do Protocolo de 1967. A ideia central era de que qualquer pessoa que fosse vítima de perseguição em seu Estado teria direito de buscar asilo e dele usufruir em qualquer país. $^{7}$

O conceito inaugural de refugiado, da Convenção de 1951, se aplicaria a todo aquele que abandonara seu país em virtude de perseguição por suas convicções políticas ou religiosas, ou por motivo de raça, cor ou nacionalidade, em razão dos acontecimentos anteriores a $1^{\circ}$ de janeiro de 1951, na Europa. A evidente preocupação com as consequências da II Guerra mostrou-se incompatível com os acontecimentos que the sucederam, gerando novas massas de refugiados carentes de proteção jurídica independentemente de uma limitação temporal ou geográfica. Assim, o conceito de refugiado foi alargado pelo Protocolo de 1967 a fim de abarcar todas as pessoas que se enquadrem na situação de perseguição em função de sua raça, credo, nacionalidade ou posição política, seja porque a perseguição é promovida pelo Estado da qual é nacional, seja porque este não consegue protege-la de quem a persegue. ${ }^{8}$ Este conceito abarca também pessoas que fogem de guerras, e de maciças violações de direitos humanos, e de catástrofes naturais que inviabilizaram a vida em seus países de origem.?

6 PIOVESAN, Flávia. Direitos Humanos e Justiça Internacional. 6 ed. São Paulo: Saraiva, 2015, p. 45-47.

7 PITA, Agni Castro. Direitos Humanos e Direito Internacional dos Refugiados. In GEDIEL, José Antônio Peres; GODOY, Gabriel Gualano de. (Org.) Refúgio e Hospitalidade. Curitiba: Kairós, 2016, p.7.

8 BARBOZA, Estefânia Maria de Queiroz; BACK, Alessandra. A proteção normativa dos refugiados políticos na América Latina e no Brasil. In GEDIEL, José Antônio Peres; GODOY, Gabriel Gualano de. (Org.) Refúgio e Hospitalidade. Curitiba: Kairós, 2016, p.92.

9 Trata-se do objeto da declaração do Secretário do Alto Comissariado das Nações Unidas para Refugiados, Aga Khan, em 1976. CAVARZERE, Thelma Thais. Direito Internacional da Pessoa Humana: A circulação internacional de pessoas. Rio de Janeiro: 
Esse Direito Internacional dos Refugiados, inaugurado com a Convenção de 1951, deve ser interpretado em consonância com o Direito Internacional dos Direitos Humanos, como ensina Cançado Trindade, pois ambos encontram fundamento nos mesmos pressupostos: toda pessoa é sujeito de direitos, em regime de igualdade para todo ser humano. Assim, um pretendente ao asilo é, antes de tudo, um titular de direitos humanos. $\mathrm{Na}$ medida em que o motivo que leva milhares de pessoas a abandonar seus países de origem é a violação dos direitos humanos, é preciso reconhecer que a proteção da pessoa humana se deve mesmo antes de consagrada a condição de refugiado. ${ }^{10} \mathrm{E}$ o reconhecimento dessa condição é verdadeiro direito dessa pessoa, e não mera discricionariedade do Estado. ${ }^{11}$

Uma questão que se pode colocar em busca de uma fundamentação ética para o direito ao refúgio ${ }^{12}$ pode-

Renovar, 1995, p. 93. Nas Américas, a Declaração de Cartagena ampliou a noção de refugiado para também proteger as vítimas de conflitos na Nicarágua, Guatemala e El Salvador, de modo que refugiados seriam "as pessoas que tenham fugido dos seus países porque a sua vida, segurança ou liberdade tenham sido ameaçadas pela violência generalizada, a agressão estrangeira, os conflitos internos, a violação maciça dos direitos humanos ou outras circunstâncias que tenham perturbado gravemente a ordem pública". PAMPLONA, Danielle Anne. PIOVESAN, Flávia. O instituto do refúgio no Brasil: práticas recentes. In Revista de Direitos Fundamentais e Democracia, v. 17, n. 17, Curitiba: janeiro/junho de 2015, p. 46.

10 CANÇADO TRINDADE, Antônio Augusto. Tratado de Direito Internacional dos Direitos Humanos. Vol. I. Porto Alegre: Sérgio Antônio Fabris, 1997, p. 270-272.

11 Nesse sentido, o campo do dever ser determina a redução do domínio da discricionariedade do Estado, a fim de que direitos universalmente assegurados sejam efetivamente implementados. Vale dizer, ao direito de solicitar refúgio e dele gozar, enunciado em documentos internacionais como a Declaração Universal, há de corresponder o dever do Estado de conceder refúgio. PIOVESAN, Flávia. Refugiados sob a Perspectiva dos Direitos Humanos. In: Seminário Internacional "Fronteiras em Movimento: Deslocamentos e outras Dimensões do Vivido", Diversitas - Núcleo de Estudos das Diversidades, Intolerâncias e Conflitos, Universidade de São Paulo, São Paulo: 2013

12 Liliana Jubilut formulou distinção que ora se adota de direito a refúgio e direito a asilo. $\mathrm{O}$ asilo corresponde ao "instituto pelo qual um Estado fornece imunidade a um indivíduo em face de perseguição sofrida por esse em outro", garantindo ao Estado poder discricionário para decidir se concede proteção a determinado indivíduo. É precisamente o caráter de perseguição política (de crença, ideologia) que fundamenta essa decisão, ou seja, trata-se de "asilo político". O refúgio é um direito do indivíduo ou grupo, e um dever do Estado, assumido soberanamente ao ratificar a Convenção para o Estatuto dos Refugiados de 1951, e seu Protocolo de 1967, estando, portanto, fora do âmbito de discricionariedade que se reconhece ao Estado quando diante de pedido de asilo. JUBILUT, Liliana. O Direito internacional dos refugiados e sua aplicação no orçamento jurídico brasileiro. São Paulo: Método, 2007, p. 37-38; 42-44. ria ser a seguinte: por que acolher? Se a resposta passa necessariamente pelo reconhecimento de que todas as pessoas são sujeito de direito, não podendo ser abandonadas quando buscam abrigo, sendo vítimas da injustiça e da perseguição, é porque se exige daqueles destinatários da obrigação de conceder o asilo ${ }^{13}$ uma tolerância ampla para com todas essas pessoas, mais ou menos diferentes deles próprios.

A tolerância como um fundamento ético para os direitos humanos dos refugiados, tal como concebidos na Convenção de 1951, e no Protocolo de 1967, tem inicialmente uma conotação universal pois dirigida a todas as pessoas, independentemente de sua origem, sua raça, sua cultura ${ }^{14}$. Como se pretende demonstrar, a tolerância de caráter universal e abstrato não tem dado conta do enfrentamento de culturas decorrente do grande afluxo de refugiados islâmicos para países ocidentais. Ela nasce com o propósito de ser cega em relação às diferenças, no lugar de procurar apontar caminhos para conviver com elas.

Para Norberto Bobbio, a tolerância diz respeito ao reconhecimento dirigido a todos que defendam ideias opostas do seu direito de existir, conviver, manifestar-se. Ela exige o método da persuasão para que os outros conheçam e eventualmente partilhem do que nós pensamos, o que jamais pode ser feito através da imposição. ${ }^{15}$ Significa dizer que dentro da lógica nacionais-

13 Marcos Wachowicz defende que o direito ao asilo, em virtude de sua íntima conexão com os direitos humanos, não pode ser compreendido como uma mera faculdade do Estado concedente, mas como verdadeiro direito humano. Apoia-se, para tanto, na Declaração Hispano-Luso-Americana de 1951, que institui que "o Direito de Asilo é um direito inerente à pessoa humana, devendo conceder-lhe o Estado solicitado, em virtude da sociabilidade universal de todos os povos". WACHOWICZ, Marcos. O direito de asilo como expressão dos direitos humanos. In Revista da Faculdade de Direito da Universidade Federal do Paraná. Curitiba: UFPR, 2002. Disponível em: www.revistas.ufpr.br/direito/article/ download/1776/1473. Acesso em 07 ago. 2016, p. 153.

14 A concepção universal dos direitos humanos, nascida com a Declaração Universal dos Direitos Humanos, tem como fundamento a dignidade da pessoa, um valor intrínseco e inerente a todo ser humano. Para universalistas, existiria um "mínimo ético irredutível" abaixo do qual não se poderia defender nenhuma prática, pois ela representaria violação dos direitos humanos. Esse universalismo admite diversos graus, dependendo da abrangência do que se possa compreender por "mínimo ético irredutível". PIOVESAN, Flávia. Direitos Humanos e o Direito Constitucional Internacional. 13 ed. São Paulo: Saraiva, 2012, p. 215, 218.

15 BOBBIO, Norberto. Elogio da serenidade e outros escritos morais. Trad. Marco Aurélio Nogueira. São Paulo: UNESP, 2002, p. 153-154. 
-estrangeiros ${ }^{16}$ personificando a dicotomia entre o 'nós' e os 'outros', a tolerância implicará que o nós respeite as ideias opostas dos outros, e todo e qualquer diálogo entre essas ideias deve fazer uso da ferramenta da persuasão, jamais da imposição. Dessa forma, ser tolerante, no contexto entre nacionais e estrangeiros refugiados, significa vencer o preconceito ${ }^{17}$ que eventualmente se tenha, para ver nos outros, sujeitos de direitos assim como nós, bem como reconhecer como válido seu direito de pensar e agir diferente.

Essa noção ideal de tolerância sofre diferentes nuances a partir do espaço político em que se manifesta. Michael Walzer, em sua obra "Da Tolerância", verificou um comportamento diferente dos grupos sociais em relação a tolerância, como sociedades internacionais, Estados-nação ou sociedades de imigrantes ${ }^{18}$.

Nas sociedades internacionais, há um regime diferenciado de estruturação social, bastante fraco politicamente e extremamente tolerante, pois todas as práticas adotadas pelos Estados soberanos que as integram são formalmente toleradas. Os Estados negociam entre si através de seus agentes diplomáticos em virtude de interesses econômicos ou até políticos comuns, e convivem com a existência de práticas internas profundamente divergentes entre si, por vezes até internamente intolerantes e violentas. Só não serão tolerados atos ou práticas que "chocam a consciência da humanidade", já

16 "Toda a lógica do Estado-nação moderno foi erigida a partir da construção da figura do estrangeiro, como o referencial negativo para a definição do nacional." Indo mais além, a dicotomia entre nós-eles, nacionais-estrangeiros, tem assumido uma feição ainda mais abissal: nós-resto. "No mesmo diapasão, Huntington elabora a categoria do "resto", como contraponto ao Ocidente. O "resto", diferente do "outro", não tem um conjunto de características independentes e consistentes de uma tribo, nação ou religião. Ele é um "aglomerado de distintas comunidades, nações e civilizações, com conjuntos diferenciados de características" (DAVUTOGLU, 2004, p. 110), mas que ficam rotuladas em sua despersonificação." OLSEN, Ana Carolina Lopes. Imigração e reconhecimento de direitos: o desafio do Brasil na era da (in)tolerância. Revista de Direito Econômico e Socioambiental, Curitiba, v. 6, n. 2, p. 122-155, jul./ dez. 2015. doi: http://www2.pucpr.br/reol/pb/index.php/direitoe conomico?dd $1=15934 \& d d 99=$ view $\& d d 98=\mathrm{pb}$. Acesso em 22 jul. 2016, p. 125; 128.

17 Segundo Bobbio, o preconceito nada mais é que uma opinião ou doutrina que é aceita de forma irrefletida e acrítica, sendo transmitida pela tradição, pelo costume ou pela autoridade legitimamente reconhecida, de modo que não se erige contra ela nenhuma posição racional. BOBBIO, Norberto. Elogio da serenidade e outros escritos morais. Trad. Marco Aurélio Nogueira. São Paulo: UNESP, 2002, p. 103.

18 WALZER, Michael. Da Tolerância. Trad. Almiro Pisetta. São Paulo: Martins Fontes, 1999, p. 22-49. que a auto-determinação dos povos não poderia ser um escudo para a selvageria. De qualquer forma, os mecanismos de repressão são fracos, já que não há uma autoridade institucionalizada para determinar condutas. ${ }^{19}$

Já nas consociações, que correspondem a Estados bi ou tri-nacionais, as comunidades diferentes através de seus líderes, e elites cooperam entre si na construção de uma estrutura jurídica que proteja seus interesses divergentes. Esses grupos sociais essencialmente diversos se unem sob um mesmo arranjo constitucional em virtude de há tempos partilharem o mesmo território, e embora pensem diferentemente, pretendem se proteger contra inimigos comuns. Mas precisam, também, tolerar-se uns aos outros, de modo que aqui a tolerância surge como uma confiança partilhada entre os membros. ${ }^{20}$

Os Estados-nação, por sua vez, tem um regime bem mais restrito de tolerância: a partir da instituição de uma só nacionalidade, uma língua, um conjunto historicamente elaborado de valores, práticas divergentes só serão toleradas de forma individual - como se dirige uma tolerância liberal às idiossincrasias alheias. ${ }^{21}$ Pouco tolerantes com os grupos, os Estados-nação podem certamente exigir que os grupos sejam tolerantes com os indivíduos, já que todos são cidadãos com os mesmos direitos. Assim, as práticas dos grupos precisam ser aprovadas pelo escrutínio das maiorias. Consequentemente, os grupos passam a se tornar associações voluntárias, com baixo poder coercitivo em razão da proteção que o Estado-nação exerce sobre os indivíduos. ${ }^{22}$

Finalmente, as organizações políticas mais tolerantes são as sociedades de imigração, pois acolhem grupos diversos que abandonaram sua terra natal para chegar

19 WALZER, Michael. Da Tolerância. Trad. Almiro Pisetta. São Paulo: Martins Fontes, 1999, p. 28-30.

20 WALZER, Michael. Da Tolerância. Trad. Almiro Pisetta. São Paulo: Martins Fontes, 1999, p. 32.

21 Como defende Stuart Mill, em On Liberty, a tolerância é a disposição em aceitar e respeitar a inviolabilidade da vida privada das pessoas, de modo que o homem deve ter liberdade total para se definir individualmente, podendo contudo ser responsabilizado pelos seus atos na medida em que eles entrem na esfera pública. Cabe ao Estado garantir o espaço sócio-político para que todos desenvolvam suas personalidades e individualidades, promovendo um ambiente urbano diversificado em que cada um possa buscar sua felicidade. WOLFF, Robert Paul. Além da Tolerância. In WOLFF, Robert Paul; MOORE JR., Barrington; MARCUSE, Herbert. Crítica da Tolerância Pura. Trad. Ruy Jungmann. Rio de Janeiro: Zahar, 1970, p. 31-34.

22 WALZER, Michael. Da Tolerância. Trad. Almiro Pisetta. São Paulo: Martins Fontes, 1999, p. 37-38. 
a um novo território, no qual se dispersaram. Para Walzer, o Estado adota uma posição neutra em relação às práticas desses grupos, pois se preocupa basicamente com a titularidade da jurisdição única. As pessoas são absolutamente livres para escolher a que grupos pertencer, que práticas adotar, desde que estas práticas não afrontem direitos de outros cidadãos. Significa dizer que a tolerância para com a pluralidade de ideias, convicções políticas e religiosas, é incentivada como uma prática de Estado, como um dever de cada cidadão. ${ }^{23}$

Os grupos, por sua vez, têm muito limitado seu acesso ao poder do Estado. Só podem ascender através dos canais institucionais definidos juridicamente, os quais definem critérios, limites e condições para efetivamente ascender à esfera pública. Muitos grupos com ideias dissonantes ficam à margem do processo político, como observa Wolff. ${ }^{24}$ Não se sabe se sobreviverão dessa forma, ou se vão se diluir em um todo, mas o respeito que esses grupos encontram nas sociedades de imigrantes é o máximo regime de tolerância.

No panorama mundial atual, quando os países europeus se deparam com a chegada de milhões de refugiados como somalis, iraquianos, afegãos e especialmente sírios, seus níveis de tolerância são colocados à prova. Como será analisado adiante, fatos veiculados pela imprensa $^{25}$ dão indícios de que a tolerância e a solidarieda-

23 Mas os grupos não podem se organizar de forma coercitiva, assumir o controle do espaço público e monopolizar recursos públicos. WALZER, Michael. Da Tolerância. Trad. Almiro Pisetta. São Paulo: Martins Fontes, 1999 p. 43.

24 Em análise da democracia pluralista norte-americana, que pode ser reconhecida como uma sociedade de imigração, verifica Wolff que somente os grupos sociais já estruturados conseguem, em competição pelo poder político, ter seus interesses satisfeitos. Dessa forma, certos grupos não conseguem ascender politicamente e suas vozes não são ouvidas, por mais razoáveis e certas que sejam. WOLFF, Robert Paul. Robert Paul. Além da Tolerância. In WOLFF, Robert Paul; MOORE JR., Barrington; MARCUSE, Herbert. Crítica da Tolerância Pura. Trad. Ruy Jungmann. Rio de Janeiro: Zahar, 1970, p. 47-48. No mesmo sentido, WALZER, Michael. Da Tolerância. Trad. Almiro Pisetta. São Paulo: Martins Fontes, 1999, p. 46-47.

25 "As cercas no leste da Europa, os muros entre os Estados Unidos e o México, as políticas de contenção nos países de origem, em sua maioria da África subsaariana (...), as devoluções da Grécia e, até mesmo, o fechamento temporário de várias fronteiras interiores na União Europeia não conseguiram frear os fluxos migratórios das 65,3 milhões de pessoas que se sentem perseguidas em seus países e cujas vidas correm perigo..." CEBRIÁN, Belén Domínguez. Guerra e perseguição tiram de suas casas 24 pessoas por minuto em todo o mundo. In: El País, Madri, 20 jun. 2016. Disponível em: http://brasil.elpais.com/brasil/2016/06/18/internacional/1466273687_619217.html. Acesso em 09 ago. 2016. $\mathrm{de}^{26}$, essenciais para o direito de refúgio, tem dado lugar ao racismo e à discriminação.

\section{O tRatamento DisPenSAdo aOS REFUGIADOS NO ACORDO UNIÃo EUROPÉIA-TURQUIA}

A fim de conter o significativo afluxo de refugiados que chegam às portas da Europa, a União Europeia celebrou com a Turquia um acordo em 18 de março de 2016. ${ }^{27}$ A Turquia foi alçada ao papel de parceira da União Europeia para o assunto de migrantes e refugiados em virtude de sua posição geográfica estratégica como porta de entrada de milhões de sírios que deixam seu país fugindo da Guerra Civil e das práticas radicais adotadas pelo Estado Islâmico, ou ISIS, bem como afegãos, iraquianos e somalis ${ }^{28}$.

Resumidamente, o acordo estabelece em sua primeira cláusula que todos os migrantes irregulares que deixarem a Turquia para adentrar a Grécia serão devolvidos ao solo turco, uma medida reconhecida como "extraordinária e temporária para pôr um fim ao sofrimento humano e restaurar a ordem pública"29. A cláusula prevê que aqueles que forem enquadrados pelas autoridades gregas como titulares do direito de asilo, terão processados individualmente seus pedidos. Os demais deverão ser retornados à Turquia.

A cláusula segunda trata especificamente dos sírios.

26 Segundo o secretário-geral da Nações Unidas, Ban Ki Moon: "Não é uma crise de números, mas uma crise de solidariedade". CEBRIÁN, Belén Domínguez. Guerra e perseguição tiram de suas casas 24 pessoas por minuto em todo o mundo. El País, Madri, 20 jun. 2016. Disponível em: http://brasil.elpais.com/brasil/2016/06/18/ internacional/1466273687_619217.html . Acesso em 09 ago. 2016. 27 "In order to break the business model of the smugglers and to offer migrants an alternative to putting their lives at risk, the EU and Turkey today decided to end the irregular migration from Turkey to the EU." GENERAL SECRETARIAT OF THE COUNCIL. EU-Turkey statement, 18 March 2016. Brussels: Press Office, 18 mar 2016. Disponível em: http:// www.consilium.europa.eu/en/press/press-releases/2016/03/18eu-turkey-statement/ Acesso em 28 jul 2016.

28 FRONTEX. Eastern Mediterranean Route. Disponível em: http:/ / frontex.europa.eu/trends-and-routes/eastern-mediterranean-route/. Acesso em 15 jul. 2016. Trata-se da chamada "Rota dos Balcãs", a partir da qual sírios, afegãos, iraquianos e até somalis deixam seus países, passam pela Turquia, e a partir dela ingressam na União Europeia percorrendo Grécia, Macedônia, Sérvia e Hungria. 29 GENERAL SECRETARIAT OF THE COUNCIL, EUTurkey statement, 18 March 2016. Brussels: Press Office, 18 mar 2016. Disponível em: http://www.consilium.europa.eu/en/press/ press-releases/2016/03/18-eu-turkey-statement/. Acesso em: 28 jul. 2016. 
Eles representam o maior contingente populacional de refugiados que chega à Europa, fugindo de uma guerra civil que dura mais de cinco anos. Segundo o Acordo, para cada sírio que seja retornado das ilhas gregas à Turquia, outro será reacomodado na União Europeia, a partir dos Critérios de Vulnerabilidade, desde que não tenha tentado entrar na União Europeia antes, irregularmente. Haveria uma disponibilidade para assentamento de 18.000 mil pessoas, sendo que a União Europeia estaria disposta a abrir vaga para mais 54.000 vulneráveis sírios. Interessante lembrar que somente em fevereiro de 2016, mais de 57.000 migrantes chegaram nas ilhas gregas, dos quais $52 \%$ eram sírios, e o restante iraquianos e afegãos. ${ }^{30}$ Com isso, a Turquia representaria o primeiro país a conceder asilo aos refugiados sírios, e de cada um que recebesse de volta e acolhesse, outro seria realocado pela própria União Europeia, para os países que estivessem em condições e disponibilidade para receber essas pessoas. ${ }^{31}$

Além disso, a fim de compensar essa devolução de sírios que buscam entrar irregularmente na Europa, a União Europeia se comprometeu em pagar uma cifra adicional de 3 bilhões de euros até 2018 (cláusula sexta), liberar o visto para turcos visitarem a Europa a partir de junho de 2016 (cláusula quinta) e facilitar os trâmites para que a Turquia venha a ser incluída na União Europeia (cláusula oitava).

O que se depreende do Acordo firmado é que, apesar do compromisso de reassentar refugiados que estejam regularmente acomodados na Turquia, todos aqueles que tentarem entrar na Europa irregularmente serão devolvidos - mesmo as vítimas da Guerra Civil Síria, e de perseguições dela decorrentes. A única porta de entrada seria pela via dos trâmites legais e burocráticos, os quais deverão ser providenciados inicialmente na Turquia. A mensagem deixada pelo Acordo é a do Presidente do Conselho Europeu: "não venham a Europa". ${ }^{32}$

Trata-se da materialização de uma tendência que já se verificava nos países industrializados especialmente a

30 COLLETT, Elizabeth. The Paradox of the EU-Turkey Refugee Deal. Migration Policy Institute, Washington, mar. 2016. Disponível em: http://www.migrationpolicy.org/news/paradox-eu-turkey-refugee-deal . Acesso em: 25 jun. 2016, p. 2-3.

31 ABELLÁN, Lucía; PÉREZ, Claudi. União Europeia e Turquia chegam a acordo para expulsar refugiados. El País. Bruxelas, 28 mar. 2016. Disponível em: http://brasil.elpais.com/brasil/2016/03/07/ internacional/1457352301_920991.html. Acesso em 20 jul. 2016, p. 2. 32 ABELLÁN, Lucía; PÉREZ, Claudi. União Europeia e Turquia chegam a acordo para expulsar refugiados, p. 4. partir da década de 90, em que barreiras físicas, legais e burocráticas foram erguidas para evitar que as pessoas que buscavam refúgio chegassem ao seu território. Verifica-se uma tendência retórica e prática de contenção dos fluxos de refugiados e migrantes, para que permaneçam em seus países, ainda que para enfrentar condições adversas em sentido econômico ou de perseguição política e jurídica. ${ }^{33}$ Especialmente porque sente que os refugiados ameaçam sua estabilidade política, social e econômica, a Europa decidiu adotar mecanismos refratores. $^{34}$

Para Collet, o Acordo EU-Turquia enfrenta um grave paradoxo. Se, de um lado, as autoridades europeias pretenderem torna-lo efetivo, precisarão atalhar mecanismos legais como proibição de detenções ou direito a recurso ${ }^{35}$ para poder devolver sírios ou outros estrangeiros que adentrarem ilegalmente suas fronteiras. Estarão comprometendo um discurso entoado há décadas com países vizinhos sobre os padrões de refúgio. Por outro lado, se decidirem cumprir fielmente todos os tratados e leis protegendo direitos humanos dessas pessoas, podem enfrentar a inviabilidade prática de promover a devolução daqueles que ingressarem irregularmente. Segundo Collet, os governos (da Europa e da Turquia) parecem estar confiando mais na mensagem do Acordo, do que na necessidade de sua efetiva implementação. ${ }^{36}$

Vale observar que um mês antes de o Acordo ser firmado, a Turquia tinha mais de duzentos mil pedidos de asilo não analisados. ${ }^{37}$ Este dado fornece uma noção

33 ACNUR. La situación de los refugiados em el mundo: en busca de soluciones. Madrid: Alianza, 1995, p. 59.

34 COLLETT, E. The Paradox of the EU-Turkey Refugee Deal. Migration Policy Institute, Washington, mar. 2016. Disponível em: http://www.migrationpolicy.org/news/paradox-eu-turkey-refugeedeal . Acesso em: 25 jun. 2016 p. 91.

35 Conforme Convenção sobre o Estatuto dos Refugiados de 1951, artigo 32 (2).

36 COLLETT, E. The Paradox of the EU-Turkey Refugee Deal. Migration Policy Institute, Washington, mar. 2016. Disponível em: http://www.migrationpolicy.org/news/paradox-eu-turkey-refugeedeal. Acesso em: 25 jun. 2016, p. 2. Conforme informa a imprensa, as devoluções já tiveram início, com levas de refugiados deixando a Grécia para a Turquia. Em abril de 2016, 600 refugiados foram devolvidos, causando manifestações contrárias e violência nos campos de refugiados. A eficácia do Acordo está sendo posta à prova na medida em que a Grécia mostra dificuldades de operacionalizar o deslocamento das pessoas em segurança, e o fluxo de chegadas de refugiados irregulares não diminuiu. COMEÇAM as novas expulsões de refugiados da União Europeia. In: El País. 4 abr. 2016. Disponível em: http://brasil.elpais.com/brasil/2016/04/03/internacional/1459712252_605155.html. Acesso: em 10 ago. 2016.

37 COMEÇAM as novas expulsões de refugiados da União Eu- 
mais próxima do que a União Europeia efetivamente pretende com o Acordo: (i) devolver todos os sírios que chegarem irregularmente as suas fronteiras para a Turquia, pois a porta de entrada só seria possível pelas vias legais; (ii) essa tramitação legal burocrática deverá ser realizada pela Turquia, apesar de ela já enfrentar dificuldades para se desincumbir do mister; (iii) somente aqueles que forem reconhecidos como refugiados sírios pela Turquia poderão ser encaminhados à Europa para assentamento em país a ser designado pela própria União Europeia ${ }^{38}$. Os números não desafiam a possibilidade de implementação da proposta, eles na verdade desmascaram a real intenção europeia: receber o menor número de refugiados possível. A Turquia que retenha, e contenha, os indesejáveis.

Um dos principais princípios postos em cheque pelo Acordo é o princípio do non-refoulement, ou da não devolução, pedra angular do Direito Internacional dos Refugiados. Segundo ele, as autoridades de um país estariam proibidas de devolver ao país de onde vieram pessoas em busca de asilo. Diferentemente da expulsão, na qual um país promove a retirada de pessoas já anteriormente admitidas, no refoulement, o Estado sequer permite que essa pessoa adentre seu território, sendo imediatamente devolvida ao seu local de origem. ${ }^{39} \mathrm{O}$ princípio do non-refoulement encontra abrigo no artigo 33, parágrafo primeiro da Convenção de 1951 sobre Direitos dos Refugiados, a qual prevê precisamente que um refugiado não pode ser retornado a um país em que sua vida ou liberdade sejam ameaçadas, precisamente em função de sua raça, religião, nacionalidade, grupo social ou opiniões políticas. ${ }^{40}$

Se as pessoas enfrentam as piores condições de

ropeia. In: El País. 4 abr. 2016. Disponível em: http://brasil.elpais. com/brasil/2016/04/03/internacional/1459712252_605155.html . Acesso: em 10 ago. 2016, p. 3.

38 Mesmo esse reconhecimento enfrenta barreiras graves como a dificuldade com a língua, ou seja, a dificuldade em articular uma narrativa, e demonstrar argumentativamente a existência das condições necessárias à configuração da qualidade de refugiado. GODOY, Gabriel Gualano de. Refúgio, Hospitalidade e os Sujeitos do Encontro. In GEDIEL, José Antônio Peres; GODOY, Gabriel Gualano de. (Org.) Refúgio e Hospitalidade. Curitiba: Kairós, 2016, p. 40-42.

39 CAVARZERE, Thelma Thais. Direito Internacional da Pessoa Humana: A circulação internacional de pessoas. Rio de Janeiro: Renovar, 1995, p. 97-98.

40 FRIEDRICH, Tatyana Scheila; BENEDETTI, Andréa Regina de Morais. A visibilidade dos Invisíveis e os Princípios de Proteção aos Refugiados: notas sobre os acontecimentos recentes. In GEDIEL, José Antônio Peres; GODOY, Gabriel Gualano de. (Org.) Refúgio e Hospitalidade. Curitiba: Kairós, 2016, p. 72. jornada possíveis para buscar um lugar que as acolha e proteja da perseguição, da fome, da privação de direitos, o princípio do non-refoulement, compreendido em consonância com os direitos humanos mais primários, justamente visa garantir que ela deve estar a salvo dessas privações. Ao lado da solidariedade, a tolerância surge como fundamento para esse princípio, no sentido de não se poder privar uma pessoa de direitos humanos em razão de sua raça, origem, convicções. Significa dizer que todas as identidades merecem respeito e acolhida quando buscam asilo, fugindo de perseguições e privações de direitos que certamente os levarão ao perecimento.

No caso do Acordo UE-Turquia, a União Europeia decide exatamente promover a devolução dos refugiados irregulares, apesar de a comunidade internacional questionar se a Turquia seria um país capaz de receber essas pessoas e evitar que sejam vítimas de perseguição e constantes violações de direitos humanos. ${ }^{41}$ Vale lembrar que ela passou por uma traumática tentativa de golpe de estado, mantém declarado estado de emergência e o atual vice-premiê anunciou a suspensão da Convenção Europeia de Direitos Humanos em seu território. ${ }^{42}$ A devolução de sírios para a Turquia significa encaminhá-los para um país que enfrenta, ele próprio, uma grave crise, com milhares de pessoas detidas e suspensão de direitos humanos.

Uma situação como essa é precisamente o que o princípio do non-refoulement visa prevenir, em se tratando de uma norma imperativa dos direitos humanos dos refugiados, a qual não poderia ser negociada ou derrogada por qualquer Acordo Internacional. ${ }^{43}$

41 Existem elementos para se responder a essa pergunta negativamente. Como salienta a Comissão Europeia para Ajuda Humanitária e Proteção Civil, a Turquia mantém cerca de 270.000 pessoas em 25 campos de refugiados, mas reconhece que $90 \%$ dos refugiados sírios que vivem fora desses campos não são considerados para dados estatísticos, e sobrevivem em condições desafiadoras, sem acesso a informação, serviços públicos como educação e saúde. EUROPEAN COMMISSION - Humanitarian Aid and Civil Protection. Turkey: Refugee Crisis. Bruxela, 2016. Disponível em: http:// ec.europa.eu/echo/files/aid/countries/factsheets/turkey_syrian_ crisis_en.pdf . Acesso em 25 jul. 2016.

42 Turquia suspende aplicação da Convenção Europeia dos Direitos Humanos. O Globo. 21 jul. 2016. Disponível em: http:// oglobo.globo.com/mundo/turquia-suspende-aplicacao-da-convencao-europeia-dos-direitos-humanos-19757361\#ixzz4H35ys1zT Acesso em 11 ago. 2016.

43 FRIEDRICH, Tatyana Scheila; BENEDETTI, Andréa Regina de Morais. A visibilidade dos Invisíveis e os Princípios de Proteção aos Refugiados: notas sobre os acontecimentos recentes. In GE- 
Outro aspecto do Acordo que merece ser considerado é que ele aumenta o tempo de espera dos egressos sírios, afegãos e iraquianos pelo efetivo reconhecimento do direito ao refúgio ${ }^{44}$, nos campos de refugiados. Estes campos abrigam tanto os pretendentes a refugiados quanto os já assim identificados, materializando um processo de exclusão social. Ainda que os refugiados assim reconhecidos e designados sejam destinatários de proteção jurídica, organismos internacionais reconhecem que eles podem ser vítimas de intimidação ou agressão em campos de refugiados, seja por parte da comunidade anfitriã que os recebe, seja por seus próprios pares. ${ }^{45}$ Mulheres e crianças são um público ainda mais vulnerável, especialmente porque se encontram em um lugar que não necessariamente respeita seus valores culturais, e com autoridades mal aparelhadas para conter os abusos.

O fato de o Direito Internacional dos Refugiados mostrar-se impotente para conter violações de direitos humanos como estas parece denunciar mais que defeitos nos arranjos jurídico-administrativos internacionais, ou problemas econômicos enfrentados pelos países receptores. Nunca foi fácil receber populações de refugiados. Como observa José Manuel Oliveira Antunes ${ }^{46}$, o fim da II Guerra Mundial implicou graves fluxos de refugiados por toda a Europa. Naquele momento his-

DIEL, José Antônio Peres; GODOY, Gabriel Gualano de. (Org.) Refúgio e Hospitalidade. Curitiba: Kairós, 2016, p. 73.

44 "O refugiado, pois, depende do reconhecimento de seu status (dos motivos fundados e subjetivos do temor que justificam a fuga) por parte de um outro Estado para readquirir, ainda que minimamente, qualquer possibilidade de acesso a direitos básicos. Embora supostamente protegido pelo guarda-chuva do direito humanitário e por agências governamentais internacionais [...], a retomada de seus direitos básicos depende, prioritariamente, de sua reintegração territorial e, por consequência, jurídica ao espaço da política governamental." MOLIN, Carolina. Os direitos humanos dos humanos sem direitos. Refugiados e a política do protesto. In Revista Brasileira de Ciências Sociais, v. 26, n. 76, São Paulo, junho, 2011, p. 145-155. Disponível em: http://www.redalyc.org/ articulo.oa?id=10719120008. Acesso em: 25 jul. 2016, p. 148.

45 "Como se demuestra por la reciente experiência de los refugiados ruandeses en Zaire y la anterior de los camboyanos en la frontera tailandesa, um campo de refugiados puede ser uno de los lugares más peligrosos del mundo, especialmente cuando está bajo el control de personas que han sido responsables de violaciones massivas de los derechos humanos en su pátria". ACNUR, $\mathbf{L a}$ situación de los refugiados en el mundo: en busca de soluciones. Madrid: Alianza, 1995, p. 59.

46 ANTUNES, José Manuel Oliveira. Refugiados: um pouco de história, para memórias curtas. In Público. Lisboa, 28 ago. 2015. Disponível em: https://www.publico.pt/mundo/noticia/refugiados-um-pouco-de-historia-para-memorias-curtas-1706138. Acesso em 10 ago. 2016. tórico, contudo, os Estados europeus enfrentavam grave destruição, de modo que os governos do pós-guerra mostraram-se por isso receptivos ao acolhimento de mão-de-obra para recompor-se. Ainda assim, como salienta Oliveira Antunes, "procuravam sempre selecionar os mais convenientes", pois a política de integração com estrangeiros sempre foi vista com reservas.

$\mathrm{Na}$ medida em que sírios, afegãos e iraquianos batem às portas em grande volume, o discurso mostra-se drasticamente menos receptivo. O incômodo que os países europeus vêm na chegada dessas populações traz em seu âmago um preconceito profundo que os tem desviado da tolerância sempre propagandeada em tratados internacionais.

\section{INTOLERÂNCIA E DISCRIMINAÇÃO: AFLUXO DE REFUGIADOS DESAFIA A SINCERIDADE DOS VALORES EUROPEUS OCIDENTAIS}

Ao longo dos últimos anos, a Europa tem sido o palco de diversos atentados terroristas. Os mais recentes, contudo, têm tido sua autoria reivindicada pelo Estado Islâmico (ISIS), traduzindo a política de intolerância desse grupo radical com o modo de viver dos europeus, e com sua política restritiva de imigração. Se de um lado a Europa tinha uma tendência de tolerar práticas religiosas diversas, desde que não comprometessem sua organização política democrática, a realidade atual tem desencadeado sentimentos xenófobos, agravando um preconceito que talvez já estivesse plantado há muitos anos.

O Acordo UE-Turquia vem justamente proteger o território europeu, mediante alegações de que os refugiados sírios, afegãos ou iraquianos trazem entre si pessoas com propósitos terroristas. Ocorre que esses refugiados estão, eles próprios, fugindo de atentados terroristas em seu próprio país ${ }^{47}$.

Nesse caso, a União Europeia não tem se comportado como uma sociedade internacional, como ensina Walzer, que adota um padrão de tolerância extremamente forte, tendo em vista que carece de uma estrutura

47 FRIEDRICH, Tatyana Scheila; BENEDETTI, Andréa Regina de Morais. A visibilidade dos Invisíveis e os Princípios de Proteção aos Refugiados: notas sobre os acontecimentos recentes. In GEDIEL, José Antônio Peres; GODOY, Gabriel Gualano de. (Org.) Refúgio e Hospitalidade. Curitiba: Kairós, 2016, p. 69-70. 
organizacional capaz de determinar obrigações e deveres, e cobrar o seu adimplemento. No caso europeu, a tolerância condicionada parece ser própria do comportamento de Estados-nação ou sociedades de imigrantes. Grupos minoritários como os refugiados sírios só são admitidos se não oferecerem nenhum risco para o modo de vida europeu, pois ao fazê-lo, justificariam medidas de contenção e intervenção.

Os indivíduos são tolerados em suas características e práticas pessoais, mas os grupos a que pertencem não gozam da mesma proteção. A título de exemplo, nas questões de gênero se percebe um delicado embate entre o direito das comunidades de manter seus rituais (uso da burka, mutilação genital, $s^{2} t^{48}$ ) e o direito individual dos cidadãos de não se sujeitar a essas práticas. $\mathrm{Na}$ medida em que tanto Estados-nação quanto sociedades de imigrantes impõe uma lei única para homens e mulheres, estes costumes encontram forte resistência. ${ }^{49}$

O choque entre a cultura europeia, e a cultura islâmica, agravada pela chegada dos refugiados tem deixado aflorar entre europeus evidente preconceito, a ser traduzido como uma compreensão a respeito de algo ou alguém, recebida e reproduzida tradicionalmente de forma acrítica, pois dotada de tanta autoridade que não admite refutação racional. ${ }^{50}$ É nessa ordem que generalizações como "muçulmanos são terroristas" ganham a força retórica de um dogma, dificultando que se olhe para os refugiados como sujeitos de direitos.

Como consequência, no lugar de uma tolerância

48 Imolação da viúva hindu sobre a pira funerária do marido. WALZER, Michael. Da Tolerância. Trad. Almiro Pisetta. São Paulo: Martins Fontes, 1999, p. 80.

49 Procurando estabelecer padrões mínimos para a tolerância, de forma mais radical, Zizek defende que a tolerância entre europeus e muçulmanos é impossível: "In short, things explode when members of a religious community consider the very way of life of another community as blasphemous or injurious, whether or not it constitutes a direct attack on their religion. To curb this propensity, one has to [...] First, formulate a minimum set of norms obligatory for everyone that includes religious freedom, protection of individual freedom against group pressure, the rights of women, etc. — without fear that such norms will appear "Eurocentric." Second, within these limits, unconditionally insist on the tolerance of different ways of life. And if norms and communication don't work, then the force of law should be applied in all its forms." ZIZEK, Slavoj. In the Wake of Paris Attacks the Left Must Embrace Its Radical Western Roots. In These Times. 16 nov. 2015. Disponível em: http://inthesetimes.com/article/print/18605/breaking-thetaboos-in-the-wake-of-paris-attacks-the-left-must-embrace. Acesso em 08 ago. 2016.

50 BOBBIO, Norberto. Elogio da serenidade e outros escritos morais. Trad. Marco Aurélio Nogueira. São Paulo: UNESP, 2002, p. 103. condicionada (e já não mais universal) surge o racismo como um preconceito em relação ao diferente, um medo de que ele causará algum mal. Essa predisposição mental dirigida a grupos inteiros, determinando o receio de que as tradições culturais dos "outros" ofusquem, comprometam ou até mesmo violem as "nossas", o medo de perder espaço no mercado de trabalho, determinando o empobrecimento e o perecimento em virtude da chegada do outro, ainda pode levar além do racismo, à xenofobia. Enquanto os valores ocidentais passam a ser considerados universais, intrinsicamente bons e justos, outros são ridicularizados e menosprezados, senão até combatidos. ${ }^{51}$

No presente caso, o choque entre valores ocidentais (Europa) e orientais (Islã), acaba ganhando corpo quando associada a problemas de caráter econômico, como a crise do Estado de Bem-Estar na Europa e o medo de que a avalanche de pessoas miseráveis inviabilize por completo o sistema. Walzer já chamava a atenção para o fato de que a intolerância se mostra ainda mais grave quando aspectos religiosos, raciais, culturais são associados a grupos economicamente subordinados. Imigrantes, quando incorporados aos grupos nacionais europeus, costumam ser tolerados porque são invisíveis. ${ }^{52}$ Mas, no caso presente, a massa de refugiados sírios está longe da invisibilidade. Neste panorama o racismo ganha força, tomando a forma de um discurso ideológico entre o bem e o mal. ${ }^{53}$

Significa dizer que pode se materializar, como se suspeita no caso do Acordo UE-Turquia, verdadeira usurpação política e ideológica do racismo, a fim de implementar a possibilidade de grupos dominantes que se pretendem homogêneos de subjugar os diferentes a

51 BOBBIO, N. Elogio da serenidade e outros escritos morais. Trad. Marco Aurélio Nogueira. São Paulo: UNESP, 2002, p. 124.

52 WALZER, M. Da Tolerância. Trad. Almiro Pisetta. São Paulo: Martins Fontes, 1999, p. 74-76.

53 Hannah Arendt, em estudo sobre o totalitarismo nazista, defendeu que seu sucesso estava intrinsicamente ligado à ideologia racista por ele implementada, a fim de afirmar a superioridade de uma raça pura ariana sobre as demais. Para ela, a raça foi a justificativa pronta e necessária para todas as atrocidades praticadas pelo nazismo, e a burocracia surgiu precisamente como o mecanismo que permitia a realização do assassinato em massa de forma desumanizada, de modo que nenhum homem poderia assumir sozinho a responsabilidade pelos atos praticados. Todos seriam membros de uma cadeia racional e jurídica que levava à aniquilação da raça considerada inferior. ARENDT, H. As origens do totalitarismo. Trad. Roberto Raposo. São Paulo: 2012, p. 238. 
partir de concepções de raça, nação, povo. ${ }^{54}$

Com isso, o racismo europeu acaba por impulsionar práticas discriminatórias ${ }^{55}$. O Acordo UE-Turquia prevê que todos os refugiados que saíram da Turquia para a Grécia de forma irregular devem ser devolvidos. Quem são os refugiados que utilizam essa rota? Essencialmente sírios, afegãos e iraquianos, ou seja, povos islâmicos. Esse acordo não abrange, por exemplo, nigerianos que cheguem à Europa por mar a partir do Líbia ${ }^{56}$. Trata-se de uma discriminação jurídica que tem levado à marginalização social ${ }^{57}$, na medida em que esses refugiados são mantidos em campos no território turco, até que se vençam os trâmites burocráticos de legalização para assentamento em solo europeu.

Como bem enfatizou Walzer, ${ }^{58}$ são os membros de uma determinada estrutura (uma nação, um Estado) que escolhem quem vão admitir, a quem vão estender os laços de afiliação, e segundo quais critérios. A fim de proteger sua liberdade, seu bem-estar social e sua cultura, os Estados devem cuidar de suas fronteiras e impor restrições de acesso ao seu território. Quanto mais fechado for o Estado, mais abertas serão as pequenas

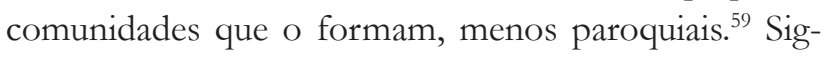

54 Não só na Europa o discurso racista foi apropriado pela direita, mas se trata de um movimento global, como se percebe das declarações proferidas pelo então candidato, hoje Presidente eleito dos Estados Unidos, Donald Trump, em entrevista relatada na New York Review of Books, em que condena as decisões de um juiz de Indiana em razão de sua origem mexicana: "This judge is of Mexican heritage. I'm building a wall". TOMASKY, Michael. Can the Monster be Elected? In The New York Review of Books. V. LXIII, n. 12, New York: jul-ago 2016, p. 42.

55 Discriminação aqui compreendida como diferenciação injusta ou ilegítima, surgindo quando aqueles que deveriam ser tratados de maneira igual, são tratados de forma diferente, em seu prejuízo. BOBBIO, Elogio da serenidade e outros escritos morais. Trad. Marco Aurélio Nogueira. São Paulo: UNESP, 2002, p. 107.

56 Além de sírios e afegãos, também eritreus, somalis e nigerianos buscam a Europa fugindo da guerra e da privação de direitos humanos. AVELAR, Daniel; BALBINO, Leda. Saiba quais são os principais conflitos que alimentam a crise de refugiados na Europa. In Folha de S. Paulo. São Paulo, 03 set. 2015. Disponível em: http:/ / www1.folha.uol.com.br/asmais/2015/09/1676793-saiba-quaissao-os-conflitos-que-alimentam-a-crise-de-refugiados-na-europa. shtml Acesso em 10 ago. 2016.

57 BOBBIO, N. Elogio da serenidade e outros escritos morais. Trad. Marco Aurélio Nogueira. São Paulo: UNESP, 2002, p. 116.

58 WALZER, Michael. Esferas da Justiça: Uma defesa do pluralismo e da igualdade. Trad. Jussara Simões. São Paulo: Martins Fontes, 2003, p. 40-41.

59 WALZER, Michael. Esferas da Justiça: Uma defesa do pluralismo e da igualdade. Trad. Jussara Simões. São Paulo: Martins Fontes, 2003, p. 48-50. nificaria afirmar que precisamente para garantir a maior amplitude possível de mobilidade dentro dos Estados que a compõe (como no Acordo Schengen, que aboliu o controle nas fronteiras internas), a União Europeia precisa adotar políticas mais restritivas para os que pretendem nela ingressar.

Menos crédulo de uma identidade cultural europeia, Lehne observa que as migrações provenientes de países europeus mais pobres ocorridas no início dos anos 2000, com o alargamento das fronteiras da União Europeia, levaram a um certo desgaste do sentimento europeu. O Acordo Schengen, para ele, não pretendia necessariamente uma unidade cultural, mas facilitar o trânsito da mão de obra dentro das fronteiras, dinamizar e desonerar as trocas comerciais. Ainda que tenha tentado dar visibilidade à pretensão da Europa de se mostrar como um território integrado, cujos cidadãos gozam de uma "área de liberdade, segurança e justiça", ${ }^{60}$ esse intento não foi atingido. Para Lehne, a Europa não criou um espaço político comum, nem uma identidade europeia que pudessem ancorar a abertura interna. Não tendo logrado formar uma comunidade transnacional que possa gerar lideranças capazes de preservar o bem comum de forma efetiva, e enfrentar assimetrias internas, a Europa tem presenciado nas últimas décadas o refortalecimento dos Estados-nação, pois são as eleições internas que distribuem poder político, e o debate público ainda está entrincheirado nas linhas nacionais.

Num primeiro momento, a crise migratória teve efeito disjuntivo, pois diante de uma política receptiva adotada pela União Europeia como um todo, os governos se voltaram para medidas restritivas nacionais, passaram a questionar o futuro do Acordo Schengen e adotar a premissa "cada um por si", em franco prejuízo para a integração europeia. ${ }^{61} \mathrm{~A}$ união só surgiu quando a estrutura europeia se viu ameaçada pela grande massa de refugiados. Identidades fragmentadas se manifestaram para cobrar de seus estados políticas de admissão mais restritivas. Foi nesse sentido que a União Europeia conseguiu um consenso entre seus 28 países para adotar o Acordo com a Turquia, e parece defender a instaura-

60 LEHNE, Stefan. The Tempting Trap of Fortress Europe. In Carnegie Europe. Bruxela, 21 abr. 2016. Disponível em: www.carnegieeurope.eu/2016/04/21/tempting-trap-of-fortress-europe/ixdx . Acesso em: 11 ago. 2016.

61 LEHNE, Stefan. The Tempting Trap of Fortress Europe. In Carnegie Europe. Bruxela, 21 abr. 2016. Disponível em: www.carnegieeurope.eu/2016/04/21/tempting-trap-of-fortress-europe/ixdx . Acesso em: 11 ago. 2016. 
ção de uma "Fortaleza Europa", com máximas restrições para a entrada de migrantes e refugiados. ${ }^{62}$

É preciso enfatizar que no caso de refugiados, segundo os padrões internacionais da Convenção de 1951, bem como dos direitos humanos, o acolhimento é quase uma imposição. Walzer demonstra essa preocupação ao lembrar que refugiados apresentam a reivindicação mais premente de todas: "Se você não me aceitar, dizem eles, serei assassinado, perseguido, brutalmente oprimido pelo governo do meu próprio país. O que podemos responder?" 63

Nesse caso, Walzer chega a sugerir que o tratamento a ser dispensado aos refugiados seja o mesmo que se teria com compatriotas, especialmente se aqueles que recebem os refugiados têm alguma responsabilidade com a condição deplorável em que se encontra seu país. Contudo, o aspecto cultural representa, para Walzer, um fator determinante. Afinidades ideológicas e étnicas atravessam fronteiras e exercem uma coerção moral que impulsiona os processos de admissão. Contrario sensu, quanto menor a identidade e a afinidade, mais difícil a receptividade dos refugiados. ${ }^{64}$

Assim, os refugiados encontram melhores políticas de admissão quando são culturalmente parecidos, de

62 "By effectively keeping refugees out of Europe in the first place, a Fortress Europe policy would greatly reduce the burden to be shared and therefore obviate the necessity of such arrangements. And the conflicts between the first $E U$ countries in which migrants arrive, the transit states, and the countries of final destination - conflicts that have bedeviled the EU's work on this issue-would disappear." Para Lehne, essa pretensão tende a falhar por diversas razões, dentre as quais a imensa fronteira terrestre e marítima da Europa, incapaz de conter os afluxos populacionais, e a precariedade da estrutura público-administrativa-policial dos países vizinhos para conter e manter em seu território os refugiados. LEHNE, Stefan. The Tempting Trap of Fortress Europe. In Carnegie Europe. Bruxela, 21 abr. 2016. Disponível em: www.carnegieeurope.eu/2016/04/21/ tempting-trap-of-fortress-europe/ixdx . Acesso em: 11 ago. 2016.

63 WALZER, Michael. Esferas da Justiça: Uma defesa do pluralismo e da igualdade. Trad. Jussara Simões. São Paulo: Martins Fontes, 2003, p. 63.

64 Walzer cita como exemplo a acolhida de refugiados políticos pela Inglaterra no século XIX, dentre os quais existiam hereges e oposicionistas diversos, em luta contra as autocracias do Centro e Leste Europeus. Como partilhavam um inimigo comum, foram bem recebidos. Ainda, o exemplo de húngaros que deixaram seu país após a revolução fracassada em 1956, já que partilhavam os valores ocidentais. Em não havendo afinidade alguma, Walzer defende que os refugiados não podem ser aceitos em detrimento de outras pessoas igualmente necessitadas. Defende a existência de fronteiras definidas. WALZER, Michael. Esferas da Justiça: Uma defesa do pluralismo e da igualdade. Trad. Jussara Simões. São Paulo: Martins Fontes, 2003, p. 64. fácil integração ${ }^{65}$, além de estarem em números administráveis. Os Estados autores do Direito Internacional dos Refugiados, ironicamente, interpretam suas normas conforme seus próprios interesses, já que não há uma autoridade supranacional legitimada a determinar compulsoriamente o seu cumprimento. Ainda mais vulneráveis estão os refugiados pois o sistema internacional de proteção não previu mecanismos para receber petições ou denúncias individuais ou entre Estados. ${ }^{66}$

Walzer afirma que o direito internacional dos refugiados foi criado para indivíduos contados um a um, o que muda severamente agravada quando se trata de milhares, ou milhões de pessoas solicitando refúgio. ${ }^{67}$ Ainda que este pedido imponha, ética e juridicamente, a aceitação, dada a sua gravidade, a realidade mostra que a política adotada pelos Estados nem sempre tem olhos para a tolerância, e para a inclusão. Para Walzer, a acolhida de grandes números de refugiados, ainda que moralmente salutar, não pode suplantar o direito de uma comunidade de restringir aqueles a quem deseja conceder a afiliação. "O princípio do auxílio mútuo só pode modificar, e não transformar, as políticas de admissão arraigadas na interpretação que determinada comunidade faz de si mesma". ${ }^{68}$

65 Arendt lembra de duas soluções de naturalização diante da crise de refugiados pós I Guerra Mundial: a naturalização dos gregos expulsos da Turquia, naturalizados em bloco em 1922, e aquela que favoreceu os refugiados armênios da Turquia estabelecidos na Síria, Líbano e outros países ex-otomanos, a qual correspondia a uma população com a qual todo o Oriente Próximo compartilhava a cidadania turco-otomana ainda poucos anos antes. ARENDT, H. As origens do totalitarismo. Trad. Roberto Raposo. São Paulo: 2012, p. 318. Michael Sandel ainda lembra do resgate dos judeus etíopes pelo Estado de Israel, em virtude da guerra civil eclodida na Etiópia em 1991. SANDEL, Michael. Justiça: O que é fazer a coisa certa. 15 ed. Rio de Janeiro: Civilização Brasileira, 2014, p. 279-280.

66 MOREIRA, Julia Bertino. Direito Internacional dos Refugiados e a Legislação Brasileira. In RAMINA, Larissa; FRIEDRICH, Tatyana Scheila (Coord). Coleção Direito Internacional Multifacetado: Direitos Humanos, Guerra e Paz. V. III. Curitiba: Juruá, 2014, p.110-111.

67 Walzer lembra a situação em que milhões de russos foram capturados pelos aliados na II Guerra Mundial e depois devolvidos compulsoriamente para a União Soviética, mesmo sabendo-se que lá muitos deles seriam assassinados. Aqueles que cientes de seu destino pediram asilo, encontraram Estados-nacionais fechados, que por motivos políticos de conveniência (não de assimilação, nem nacionalidade) o negaram. WALZER, M. Esferas da justiça. Uma defesa do pluralismo e da igualdade. Trad. Jussara Simões. São Paulo: Martins Fontes, 2003, p. 66.

68 WALZER, M. Esferas da justiça. Uma defesa do pluralismo e da igualdade. Trad. Jussara Simões. São Paulo: Martins Fontes, 2003 , p. 67. 
A defesa de Walzer se justifica dentro de uma concepção comunitarista de sociedade. Todavia, se essa concepção implica a larga violação de direitos humanos essenciais à sobrevivência do homem, ela pode ser questionada. Enviar para o risco de morte grandes contingentes humanos não poderia ser justificado a partir de valores culturais comunitários.

$\mathrm{Na}$ verdade, bem andou Collet ao ressaltar o paradoxo em que o Acordo UE-Turquia colocou a comunidade ocidental europeia. ${ }^{69}$ Enquanto procura se fechar em uma fortaleza para preservar sua cultura, seus valores seculares, exclui de seu território os mais necessitados, determinando a devolução de refugiados. Ao fazê-lo, acaba por violar aqueles mesmos valores que pretendia proteger, como a tolerância para com o diferente, a inclusão, a isonomia. ${ }^{70}$ Se abrir completamente suas fronteiras, por outro lado, teme a União Europeia que, diante do grande afluxo de refugiados de culturas muito diversas, veja diluída e dissolvida mesma cultura.

A questão que fica é se seria possível pensar em recuperar e remodelar a tolerância como fundamento do direito dos refugiados, a fim de direcionar sua interpretação para uma prática de inclusão e respeito.

\section{Perspectivas para a recuperação ou REMODELAÇÃO DA TOLERÂNCIA}

69 No mesmo sentido a crítica feita por Sam Kriss a Zizek: "What kind of Lacanian tells someone that they should effectively abandon their desire for something just because it's not attainable? Or are migrants not worthy of the luxury of an unconscious mind?) In Calais, migrants trying to reach the United Kingdom protested against their conditions with placards demanding "freedom of movement for all." Unlike racial or gender equality, the free movement of peoples across national borders is a supposedly universal European value that has actually been implemented - but, of course, only for Europeans. These protesters put the lie to any claim on the part of Europe to be upholding universal values". ZIZEK, Slavoj. In the Wake of Paris Attacks the Left Must Embrace Its Radical Western Roots. In These Times. 16 nov. 2015. Disponível em: http://inthesetimes.com/article/print/18605/breaking-thetaboos-in-the-wake-of-paris-attacks-the-left-must-embrace. Acesso em 08 ago. 2016.

70 Se os europeus ocidentais defendem que sua cultura enaltece a dignidade de cada pessoa humana, que todos são iguais e merecem os mesmos direitos, direito ao respeito a sua própria tradição, religião, raça, como justificar a barbarização do outro? AMADO, Juan Antonio García. ?Por qué no tienen los Inmigrantes dos Mismos Derechos que los Nacionales? In ARNAUD, André-Jean. Globalização e Direito I: Impactos nacionais, regionais e transnacionais. 2 ed. Rio de Janeiro: Lumen Iuris, 2005, p. 471-472.
A defesa dos direitos humanos dos refugiados não admite a possibilidade de condicionamentos ${ }^{71}$. Essa afirmação encontra-se amparada em uma concepção universal de direitos humanos que reconhece igualmente em cada pessoa um sujeito de direitos, que não pode ser deportado ou abandonado para perecer. Por fundamento, defende uma máxima tolerância para com a figura do outro, a fim de nele reconhecer um titular de direitos, de modo que sua qualificação como refugiado sírio não poderia ser suficiente para determinar sua devolução, ainda que chegue irregularmente.

A questão merece ser enfrentada à luz de uma alegação que partidários da Europa fazem como justificativa para fechar suas fronteiras, qual seja, a que dentre os refugiados sírios infiltram-se membros do Estado Islâmico que adentram território europeu com o objetivo de praticar atos terroristas. Diante dessa questão, seria necessário questionar se seria exigível ser tolerante também nesses casos.

É preciso esclarecer que não se trata de ser tolerante com terroristas, no sentido de admitir indiscriminadamente pessoas que se sabe ou se tem fundado receio de ser um criminoso. As redes de segurança europeia e internacional têm, de fato, que promover as devidas investigações a fim de localizar e levar a julgamento aqueles que praticam atos contrários aos direitos humanos, como o são os atos terroristas. A questão aqui é que não se pode presumir que as pessoas que deixam a Síria fugindo da intolerância de Bashar al-Assad, de um lado, e do Estado Islâmico, de outro, sejam todas convictos ou potenciais terroristas. Admitir essa presunção vai além de deitar por terra princípios caros ao Estado de Direito, implica a mais franca e desmedida xenofobia.

Refugiados sírios são devolvidos, barrados por muitos estados europeus sem qualquer rastro de tolerância ou solidariedade porque, segundo Walzer, os europeus não conseguem estabelecer com eles um laço de identidade - seja étnica, política, ideológica ou ainda cultural. Indo além, essas diferenças identitárias justificariam a proteção dos recursos econômicos em certa medida já escassos para os compatriotas. Todavia a Europa não logrou demonstrar a total impossibilidade de acolher os refugiados sírios. Talvez esse acolhimento - no grande

71 PAMPlONA, Danielle Anne; PIOVESAN, Flávia. O instituto do refúgio no Brasil: práticas recentes. In Revista de Direitos Fundamentais e Democracia, v. 17, n. 17, Curitiba: janeiro/junho de 2015, p. 51. 
volume como se apresenta - comprometesse o padrão de vida hoje mantido por muitos europeus, mas por certo não os levaria à fome e à miséria. Sandel, pensando sobre a possibilidade de se negar acesso ao Estado em função da preservação dos privilégios econômicos dos nacionais, rechaça essa possibilidade. Seria o mesmo que imaginar que somente as pessoas que tiveram a sorte de nascer naquele território tem direito de serem ricas. ${ }^{72}$

Ainda que o problema econômico possa ser questionado, a questão central parece ser mais simples: preconceito, racismo, xenofobia. Sentimentos que dificilmente serão afastados por um ideal universal de que todos partilham da mesma humanidade, pois são muito concretos e presentes. Como observa Silva, tornou-se hegemônico considerar como inferiores pessoas que não participam do mesmo grupo social, quando "não encontramos um pouco de nós mesmos nesse outro". ${ }^{73}$ Essa dificuldade vem em razão de valores morais que diferem profundamente, como, no caso islâmico, o tratamento dispensado às mulheres, a laicidade do Estado, e o comprometimento religioso. Com esse nível de discordância, o recurso a um ser humano abstrato e universal não facilita o diálogo.

Richard Rorty observa que a solidariedade entre os grupos sociais surge precisamente em função de uma maior proximidade (étnica, política, religiosa) que possa haver entre eles. Para ele, maior será a solidariedade "quando aqueles com quem nos solidarizamos são vistos como 'um de nós', expressão em que 'nós' significa algo menor e mais local do que a raça humana". Se as semelhanças e diferenças entre os grupos são construídas de forma histórica e contingencial, uma solução universal abstrata seria de difícil sustentação. "É por isso que a frase 'porque essa pessoa é um ser humano' constitui uma explicação pouco convincente para um ato generoso." ${ }^{74}$

Para Rorty, mesmo sem se recorrer a matrizes universalistas, é possível defender que grupos identificados

72 SANDEL, Michael. Justiça: O que é fazer a coisa certa. 15 ed. Rio de Janeiro: Civilização Brasileira, 2014, p. 284. "Já que o acaso do local de nascimento não justifica o merecimento do direito [...] é difícil conceber como a restrição à imigração pode ser justificada em nome da preservação da riqueza". Se não se opõe a migrantes econômicos, em hipótese alguma se oporia a refugiados.

73 SILVA, Sérgio Gomes da. Direitos humanos: entre o princípio de igualdade e a tolerância. In Revista Praia Vermelha, v. 19, n. 1. Rio de Janeiro, jan-jul 2010, p. 80.

74 RORTY, Richard. Contingência, Ironia e Solidariedade. Trad. Vera Ribeiro. São Paulo: Martins Fontes, 2007, p. 313-315. como "nós" busquem alargar seu conceito para serem solidários com aqueles que inicialmente consideravam como "eles". Esse progresso moral caminharia no sentido de gerar uma maior solidariedade entre os homens, porém não em função de um "eu nuclear" que possa ser identificado em toda a humanidade, mas em função de um maior desprezo sobre as diferenças tradicionais (origem, religião) e uma maior preocupação em torno de questões como dor e humilhação. ${ }^{75}$ Significaria ver no "outro" alguém que, tão historicamente e contingencialmente informado como "nós", tem os mesmos sentimentos.

A partir dessa proximidade, Rorty sugere acolher aqueles em que ordinariamente se pensa como "eles" para quem passem a ser "nós", no lugar de pensar em termos absolutos como se essa solidariedade existisse num momento pré-existente, como condição humana ${ }^{76}$. Esse "nós" não pode ser visto a partir de um mero etnocentrismo, mas de um etnocentrismo que coloca em dúvida a si mesmo, que questiona sobre sua capacidade de enxergar o outro.

Para Silva, não pode haver uma tolerância incondicional em relação ao outro, pois a tolerância sempre se dirige ao diferente a partir de certas condições que nós estabelecemos como válidas, pressupostos mínimos de aceitação. Para Silva, a tolerância incondicional seria caridade, e, portanto, uma espécie de dominação; ou seria então indiferença, mera aceitação do outro diante da inevitabilidade da vida em comum. Em nenhum desses casos, ela gera solidariedade. Em diálogo com as ideias de Rorty, defende que a tolerância deve propiciar alguma espécie de vínculo com o outro, de modo que ele possa ser visto como "nós", segundo uma categoria de "nós" contingencial e aberta. ${ }^{77}$

Nessa linha, uma situação seria perguntar ao outro se ele tem ou deseja ter as mesmas convicções que nós;

75 RORTY, Richard. Contingência, Ironia e Solidariedade. Trad. Vera Ribeiro. São Paulo: Martins Fontes, 2007. p. 316.

76 Este "nós" poderia ser compreendido como "nós, herdeiros das contingências históricas que criaram instituições políticas cada vez mais cosmopolitas e cada vez mais democráticas". RORTY, R. Contingência, Ironia e Solidariedade. Trad. Vera Ribeiro. São Paulo: Martins Fontes, 2007, p. 322-323.

77 "A tolerância incondicional é algo desejável, porém, impossível. Nenhuma sociedade, nenhum grupo social ou comunidade, nenhum ser humano em lugar algum do mundo pode ser totalmente tolerante para com seu "irmão em humanidade". SILVA, Sérgio Gomes da. Sérgio Gomes da. Direitos humanos: entre o princípio de igualdade e a tolerância. In Revista Praia Vermelha, v. 19, n. 1. Rio de Janeiro, jan-jul 2010, p. 90-91. 
outra, bem diferente, seria perguntar se ele está sofrendo. É na preocupação com a segunda resposta que a questão da solidariedade se apresenta de forma concreta e real. ${ }^{78}$

Seguindo esse mesmo caminho, e ciente de um mundo em que as diversidades culturais se chocam, Kwame Anthony Appiah propõe o cosmopolitismo como uma concepção de mundo fundada em duas noções: a de que as pessoas têm obrigações para com as outras, as quais transcendem os laços de família, ou cidadania; e a de que as vidas humanas em particular têm valor em si, o que traduz uma preocupação com práticas culturais identitárias. $^{79}$

Segundo Appiah, existem dois níveis de discordância sobre valores, o fraco, e o forte. No primeiro, encontram-se os padrões de certo, errado, belo, feio, sobre os quais praticamente todas as sociedades se posicionam, tendo práticas que se enquadram nestas categorias. No segundo, existem conceitos culturalmente profundos que não são partilhados, porque uma cultura simplesmente não tem o mesmo referente que a outra. Nesse caso, a discordância deve ser resolvida não com a aceitação do outro valor, ou sua incorporação, mas apenas com a sua compreensão. ${ }^{80} \mathrm{~A}$ tolerância - no sentido de reconhecimento - parte do diálogo com o outro, de modo a permitir que as duas culturas compreendam uma a outra, ainda que não concordem sobre determinados pontos. A "Regra de Ouro", segundo Appiah, é levar em consideração a ideia dos outros, sua concepção de mundo, seus interesses. É importante que as pessoas conheçam essa realidade alternativa, e experimentem, ainda que na imaginação, como seria vive-la. ${ }^{81}$

78 RORTY, R. Contingência, Ironia e Solidariedade. Trad. Vera Ribeiro. São Paulo: Martins Fontes, 2007, p. 326.

79 APPIAH, Kwame Anthony. Cosmopolitanism: Ethics in A World of Strangers. (e-book) New York: Penguin, 2007, p. 15.

80 APPIAH, Kwame Anthony. Cosmopolitanism: Ethics in A World of Strangers. (e-book) New York: Penguin, 2007, p. 102. Em outro trecho, o mesmo autor enfatiza que o relativismo cultural não leva ao diálogo: "Porque se o relativismo sobre ética e moralidade for verdadeiro, então, ao final de muitas discussões, cada um de nós acabaria dizendo: 'Do meu ponto de vista, estou certo. Do seu ponto de vista, você está certo'. E não haveria mais nada a dizer. [...] As pessoas sempre recomendam o relativismo porque entendem que ele levará à tolerância. Mas, se não pudermos aprender com o outro o que é certo pensar e sentir e fazer, então, a conversa entre nós será sem objeto. Relativismo deste tipo não é uma forma de se encorajar a conversa; é só uma razão para ficar em silêncio." (Tradução livre). P. 77.

81 APPIAH, Kwame Anthony. Cosmopolitanism: Ethics in A World of Strangers. (e-book) New York: Penguin, 2007, p. 130.
No caso em exame, o preconceito, o racismo e a xenofobia que transparecem a partir do Acordo UE-Turquia não pode ser vencido por uma ideia abstrata de tolerância para com o estrangeiro apenas porque são todos - europeus e sírios - da mesma espécie humana, nem por uma ideia que encerre possibilidade de diálogo em torno de diferenças culturais invencíveis. ${ }^{82}$ Entre os dois extremos, o cosmopolitismo propõe que um saiba calçar os sapatos do outro, e procurar entender suas necessidades, suas urgências. No caso dos refugiados sírios, o que também se aplica aos demais que buscam asilo na Europa, a luta pela própria sobrevivência é algo que transparece de sua própria existência pessoal, e precisa ser compreendida pelo povo europeu, precisa ser conhecida em concreto. Como bem assinala Appiah, "quando o estrangeiro não é mais imaginário, mas real e presente, compartilhando uma vida humana social, você pode gostar ou desgostar dele, pode concordar ou discordar; mas, se é o que vocês dois querem, vocês podem fazer sentido um do outro ao final". 83

Dentro dessa proposta cosmopolita, Fachin propõe uma concepção de tolerância como fundamento inarredável para o diálogo entre as culturas, e superação do preconceito. No plano intrínseco a um sistema cultural, a tolerância permitiria reconhecer a validade das tradições culturais de um lado, e a autonomia individual de se submeter ou não a elas. ${ }^{84}$ No plano extrínseco, a tolerância representa o pressuposto para o diálogo intercultural a fim de evitar a imposição de um padrão cultural hegemônico. ${ }^{85}$

Heller e Feher também se ocuparam da necessidade de identificação de virtudes cívicas a serem desenvolvidas na vida em sociedade, precisamente a fim de permitir uma vida em comum diante das mais diversas cultu-

82 FACHIN, Melina Girardi. Fundamentos dos Direitos Humanos: Teoria e práxis na cultura da tolerância. Rio de Janeiro: Renovar, 2009, p. 271.

83 APPIAH, Kwame Anthony. Cosmopolitanism: Ethics in A World of Strangers. (e-book) New York: Penguin, 2007, p. 187.

84 Nesse sentido, recebem melhor acolhida no mundo ocidental pessoas que fogem dos sistemas islâmicos porque não desejam se submeter a eles, como no caso narrado por Khadija Kafir, que se insurgiu contra a tradição islâmica de sua família e logrou sobreviver com a ajuda de ocidentais, trocando de identidade. KAFIR, Khadija; JAMES, Sabatina. Por que minha mãe me quer morta. In Ex-muçulmanos. 1 set. 2015. Disponível em: < http://www.exmuculmanos. com/por-que-minha-mae-me-quer-morta/>. Acesso em 12 ago. 2016.

85 FACHIN, Melina Girardi. Fundamentos dos Direitos Humanos: Teoria e práxis na cultura da tolerância. Rio de Janeiro: Renovar, 2009, p. 280-281. 
ras. Propõem o conceito de tolerância radical, partindo da premissa de que todas as pessoas devem ter iguais oportunidades de vida.

Assim, a partir do reconhecimento de que todas as necessidades humanas merecem indistintamente ser atendidas (afastadas aquelas que usam outras pessoas como meios e podem impedir de se reconhecer necessidades para todos), também merecem reconhecimento diferentes formas de vida. ${ }^{86}$ Esse reconhecimento vai além da tolerância liberal (pela qual cada um pode perseguir individualmente seu ideal de felicidade, num sentido de não ingerência na liberdade alheia), pois tem uma conotação positiva, na medida em que determina uma relação ativa com o outro. A tolerância radical não aceita a força, a violência da dominação, autorizando o combate a todas as leis que negam o reconhecimento das formas de vida. Essa modalidade de tolerância vai além do "isso não é da minha conta" para implicar o "eu me importo". ${ }^{87}$

É precisamente a ideia de se importar com o outro que motiva a solidariedade. Ela deve estar relacionada com a tolerância radical e a coragem cívica, sendo informada pelos valores universais da vida e liberdade, igualdade e racionalidade comunicativa. A solidariedade enquanto virtude deve ser traduzida em atos concretos de apoio aos grupos, movimentos sociais, comunidades, a fim de reduzir o nível de violência, dominação ou força nas instituições sociais e políticas. Não se trata de apoio irrestrito ao grupo, justamente exclui essa ideia na medida em que impõe condições: solidariedade a todos os grupos que reduzem a dominação, a força e a violência e ampliam o espaço de liberdade para todos. ${ }^{88}$ Nessa linha, não se falaria em solidariedade para com o Estado Islâmico (ISIS), mas sim para com suas vítimas.

A fim de instrumentalizar a solidariedade, Appiah

86 Nesse mesmo sentido, a solidariedade para com estrangeiros, como observado por Appiah, não exige que se nutra por eles o mesmo sentimento de simpatia que se tem pelos vizinhos, ou familiares e amigos. Partindo do princípio de que esse sentimento não está presente na maior parte das vezes, a solidariedade se dirige ao reconhecimento de que todas as pessoas têm necessidades básicas, como alimentação, abrigo, saúde, educação. APPIAH, Kwame Anthony. Cosmopolitanism: Ethics in A World of Strangers. (e-book) New York: Penguin, 2007, p. 279.

87 HELLER, Agnes; FEHÉR, Ferenc. A condição política pósmoderna. Trad. Marcos Santarrita. Rio de Janeiro: Civilização Brasileira, 1998, p. 122-124.

88 HELLER, Agnes; FEHÉR, Ferenc. A condição política pósmoderna. Trad. Marcos Santarrita. Rio de Janeiro: Civilização Brasileira, 1998, p. 126. defende que as necessidades básicas de sobrevivência devem ser supridas, primeiramente, pela estrutura dos estados, de modo que os cidadãos têm responsabilidade de tomar providências para que esses estados atendam às necessidades de seus próprios nacionais. Indo além, na medida em que se aceita a estrutura política dos estados-nação, necessário reconhecer que as pessoas também têm um papel a cumprir na garantia de que outros estados garantam as necessidades de seu próprio povo, sem que isso signifique que cada um deva levar nas costas o peso da ineficiência, da corrupção ou mesmo da tirania alheia. ${ }^{89}$ A grande dificuldade está precisamente em determinar esse papel.

É certo que a solidariedade para com estrangeiros não pode inviabilizar a solidariedade/responsabilidade que cada um tem para com sua própria família, para com as pessoas que dele dependem ou procuram. Também não pode exigir que, em nome do cuidado para com o outro, alguém abandone os cuidados para consigo próprio. ${ }^{90}$

O cosmopolitismo exige que as pessoas se preocupem com os outros no sentido de procurar se informar sobre soluções razoáveis para os problemas. Não basta o engajamento, mas é preciso ter curiosidade, afinal é possível que certos cidadãos sejam coniventes com políticas que estão causando morte a outros, distantes de seus olhos. É preciso investigar por que grandes montantes financeiros são enviados para países pobres e não se vê melhora alguma na condição de vida de seus cidadãos. Como diz Appiah, "ele envolve não apenas ver uma pessoa sofrendo, mas uma vida humana desperdiçada". ${ }^{11}$

A solidariedade para com os estrangeiros não exige heroísmo, mas bom senso. Como fora salientado pela Conferencia de Direitos Humanos de 1993, trata-se de compartilhar responsabilidades, de modo que a comunidade internacional adote um planejamento abrangente a fim de coordenar atividades e promover uma maior cooperação com países envolvidos nas crises de refugia$\operatorname{dos}^{92}$. Para Appiah, trata-se de exigir dos representantes

89 APPIAH, Kwame Anthony. Cosmopolitanism: Ethics in A World of Strangers. (e-book) New York: Penguin, 2007, p. 288-289.

90 APPIAH, Kwame Anthony. Cosmopolitanism: Ethics in A World of Strangers. (e-book) New York: Penguin, 2007, p. 292.

91 APPIAH, Kwame Anthony. Cosmopolitanism: Ethics in A World of Strangers. (e-book) New York: Penguin, 2007, p. 297.

92 PIOVESAN, Flávia. Refugiados sob a Perspectiva dos Direitos Humanos. In: Seminário Internacional "Fronteiras em 
políticos que eles se lembrem dos estrangeiros, não porque estejamos chocados com seu sofrimento - até podemos estar - mas porque a sociedade responde à razão, a princípios, à consciência. Por mais distante, ou próximo, que os estrangeiros estejam, eles merecem viver. ${ }^{93}$

\section{Considerações finais}

Diante do exposto, é possível verificar, como já afirmara Zizek, que vivemos em tempos interessantes ${ }^{94}$. Tempos em que instrumentos normativos foram criados para vincular os Estados ao valor ético da pessoa humana, à sua dignidade. Como se depreende do Direito Internacional dos Refugiados, interpretado à luz dos direitos humanos, toda pessoa que se vê forçada a abandonar seu país em razão de perseguição, de medo da morte, da tortura, tem o direito de ser acolhida por comunidades estrangeiras, e protegida na qualidade de refugiada.

Todavia, a previsão abstrata de que todos partilhamos a mesma raça humana não foi motivo suficiente para que a Europa - conhecida mundialmente como berço dos direitos humanos - vencesse o preconceito em relação a grupos profundamente diferentes do seu ideal de bem viver. Quando as fronteiras europeias se viram assediadas por milhares de refugiados sírios, iraquianos, afegãos, o choque de civilizações falou mais alto, dando lugar ao preconceito, ao racismo e à xenofobia. O Acordo firmado pela União Europeia com a Turquia é talvez a expressão mais evidente dessa realidade, admitindo a devolução de refugiados que chegam às ilhas gregas para a Turquia. $\mathrm{O}$ princípio básico do Direito dos Refugiados, o non-refoulement parece ter sido esquecido. O Acordo prevê ajuda financeira dos países europeus para que a Turquia, ela própria enfrentando graves problemas políticos internos, inclusive de origem religiosa, acolha as massas de refugiados sírios. Ainda que preveja a possibilidade de reassentamento de refu-

Movimento: Deslocamentos e outras Dimensões do Vivido", Diversitas - Núcleo de Estudos das Diversidades, Intolerâncias e Conflitos, Universidade de São Paulo, São Paulo: 2013.

93 APPIAH, Kwame Anthony. Cosmopolitanism: Ethics in A World of Strangers. (e-book) New York: Penguin, 2007, p. 307-308.

94 ZIZEK, Slavoj. In the Wake of Paris Attacks the Left Must Embrace Its Radical Western Roots. In These Times. 16 nov. 2015. Disponível em: http://inthesetimes.com/article/print/18605/ breaking-the-taboos-in-the-wake-of-paris-attacks-the-left-must-embrace. Acesso em 08 ago. 2016: "We definitely live in interesting times." giados legalmente instalados em solo turco nos países europeus, os números acabam por mostrar que a intenção da União Europeia de cumprimento de sua parte no acordo é, no mínimo, duvidosa.

Nesse sentido, a tolerância universal, idealizada, abstrata que deveria marcar as relações sociais entre povos diferentes mostrou-se um conceito de baixa operacionalidade. Os choques culturais entre refugiados sírios e o povo europeu são gritantes e concretos, além de terem sido agravados por atentados terroristas que apenas colocaram a Europa ainda mais "fortificada", para usar a expressão de Lehne. O Acordo UE-Turquia evidencia o fechamento de fronteiras em razão da intolerância, não apenas para com os terroristas em si, ou para com o Estado Islâmico (ISIS), mas também para com suas vítimas.

Diante desse quadro, sugere-se pensar a tolerância dirigida a sujeitos concretos, reconhecidos em sua historicidade, sua existência cultural e, nesta seara, sua dignidade. A partir das lições de Rorty, com seu conceito alargado de "nós" e Appiah, para quem os abismos culturais podem não se resolver pela aceitação, mas por um diálogo de compreensão. Urge pensar nos refugiados como pessoas concretas, com histórias que impõe a responsabilidade daquele a quem chegam, pela sua gravidade e premência.

Não se exige do europeu que ele abandone suas convicções para compreender as necessidades dos refugiados; sua estrutura ético-jurídica fornece um instrumental adequado para tanto na medida em que defende a liberdade religiosa, os direitos básicos essenciais à sobrevivência. Ele só precisa ser utilizado com sinceridade. A partir do respeito às normas de direitos humanos, conhecer o outro e nele reconhecer um sujeito de direitos. O preconceito, como bem colocado por Bobbio, nasce na cabeça dos homens, e só pode ser nela combatido, a partir da construção de uma consciência voltada para a tolerância. ${ }^{95}$

Tolerância radical, como defendem Heller e Fehér, que assume uma feição ativa para além do ideal liberal, defensor de uma liberdade plena para se nutrir convicções e com base nelas pautar uma existência. Uma feição ativa que se dirija ao outro e compreenda suas razões, suas necessidades, e em função desse encontro paute condutas de respeito e de acolhimento.

95 BOBBIO, Norberto. Elogio da serenidade e outros escritos morais. Trad. Marco Aurélio Nogueira. São Paulo: UNESP, 2002, p. 117. 
É certo que a realidade vivida hoje desafia a praticidade dessas noções. O contingente de refugiados é imenso, talvez sua acolhida implique sacrifícios para a Europa. O medo do terrorismo é igualmente avassalador. Não há caminhos fáceis para solucionar o choque de intenções, pois os europeus dificilmente conseguirão se isolar diante do grande contingente de necessitados. E ao fazê-lo, estariam negando a si mesmos. Ciente dessas limitações, o próprio Direito Internacional dos Refugiados sugere que se combatam as causas do refúgio, mediante ações solidárias que possam impedir/punir perseguições dos nacionais em seus próprios estados, e permitir que eles sejam devolvidos aos seus lares. ${ }^{96}$ Medidas contra o terrorismo devem ser tomadas com investigações dedicadas, e punições seguras, não com exclusão de pessoas por presunções que só se sustentam enquanto manifestações racistas e xenofóbicas.

Se a dificuldade é grande, maior há de ser a superação. Como sugere o cosmopolitismo, não há necessidade de heróis, mas de efetivamente nos ocuparmos em enxergar os outros, cobrar dos Estados ações concretas e senão ética, juridicamente comprometidas com os direitos humanos. Em tempos de individualismo, talvez aí já haja uma boa dose de heroísmo. De fato, tempos interessantes.

\section{REFERÊNCIAS}

ABELLÁN, Lucía; PÉREZ, Claudi. União Europeia e Turquia chegam a acordo para expulsar refugiados. E1 País. Bruxelas, 28 mar. 2016. Disponível em: http:// brasil.elpais.com/brasil/2016/03/07/internacional/1457352301_920991.html. Acesso em 20 jul. 2016.

ACNUR. La situación de los refugiados en el mundo: en busca de soluciones. Madrid: Alianza, 1995.

AMADO, Juan Antonio García. ?Por qué no tienen los Inmigrantes dos Mismos Derechos que los Nacionales? In ARNAUD, André-Jean. Globalização e Direito I: Impactos nacionais, regionais e transnacionais. 2 ed. Rio de Janeiro: Lumen Iuris, 2005.

ANTUNES, José Manuel Oliveira. Refugiados: um pouco de história, para memórias curtas. In Público. Lisboa, 28 ago. 2015. Disponível em: https://www.

96 ACNUR. La situación de los refugiados en el mundo: en busca de soluciones. Madrid: Alianza, 1995, p. 62-63. publico.pt/mundo/noticia/refugiados-um-pouco-dehistoria-para-memorias-curtas-1706138. Acesso em 10 ago. 2016.

APPIAH, Kwame Anthony. Cosmopolitanism: Ethics in A World of Strangers (e-book). New York: Penguin, 2007.

ARENDT, Hannah. As origens do totalitarismo. Trad. Roberto Raposo. São Paulo: 2012.

AVELAR, Daniel; BALBINO, Leda. Saiba quais são os principais conflitos que alimentam a crise de refugiados na Europa. In Folha de S. Paulo. São Paulo, 03 set. 2015. Disponível em: http://www1.folha.uol.com. br/asmais/2015/09/1676793-saiba-quais-sao-os-conflitos-que-alimentam-a-crise-de-refugiados-na-europa. shtml. Acesso em 10 ago. 2016.

BARBOZA, Estefânia Maria de Queiroz; BACK, Alessandra. A proteção normativa dos refugiados políticos na América Latina e no Brasil. In GEDIEL, José Antônio Peres; GODOY, Gabriel Gualano de. (Org.) Refúgio e Hospitalidade. Curitiba: Kairós, 2016, p. 87-117.

COLLET'T, Elizabeth. The Paradox of the EU-Turkey Refugee Deal. Migration Policy Institute, Washington, mar. 2016. Disponível em: http://www.migrationpolicy. org/news/paradox-eu-turkey-refugee-deal . Acesso em: 25 jun. 2016.

BOBBIO, Norberto. Elogio da serenidade e outros escritos morais. Trad. Marco Aurélio Nogueira. São Paulo: UNESP, 2002.

CAVARZERE, Thelma Thais. Direito Internacional da Pessoa Humana: A circulação internacional de pessoas. Rio de Janeiro: Renovar, 1995.

CEBRIÁN, Belén Domínguez. Guerra e perseguição tiram de suas casas 24 pessoas por minuto em todo o mundo. In E1 País, Madri, 20 jun. 2016. Disponível em: http://brasil.elpais.com/brasil/2016/06/18/internacional/1466273687_619217.html. Acesso em: 09 ago. 2016.

COMEÇAM as novas expulsões de refugiados da União Europeia. E1 País. 4 abr. 2016. Disponível em: http://brasil.elpais.com/brasil/2016/04/03/internacional/1459712252_605155.html Acesso em 10 ago. 2016.

EUROPEAN COMMISSION - Humanitarian Aid and Civil Protection. Turkey: Refugee Crisis. Bruxela, 2016. Disponível em: http://ec.europa.eu/echo/files/ 
aid/countries/factsheets/turkey_syrian_crisis_en.pdf . Acesso em 25 jul. 2016.

FACHIN, Melina Girardi. Fundamentos dos Direitos Humanos: Teoria e práxis na cultura da tolerância. Rio de Janeiro: Renovar, 2009.

FRIEDRICH, Tatyana Scheila; BENEDETTI, Andréa Regina de Morais. A visibilidade dos Invisíveis e os Princípios de Proteção aos Refugiados: notas sobre os acontecimentos recentes. In GEDIEL, José Antônio Peres; GODOY, Gabriel Gualano de. (Org.) Refúgio e Hospitalidade. Curitiba: Kairós, 2016, p. 67-85.

FRONTEX. Eastern Mediterranean Route. Disponível em: http://frontex.europa.eu/trends-and-routes/eastern-mediterranean-route/. Acesso em 15 jul. 2016.

GENERAL SECRETARIAT OF THE COUNCIL. EU-Turkey statement, 18 March 2016. Brussels: Press Office, 18 mar 2016. Disponível em: http:/ /www.consilium.europa.eu/en/press/press-releases/2016/03/18eu-turkey-statement/ Acesso em: 28 jul 2016.

GODOY, Gabriel Gualano de. Refúgio, Hospitalidade e os Sujeitos do Encontro. In In GEDIEL, José Antônio Peres; GODOY, Gabriel Gualano de. (Org.) Refúgio e Hospitalidade. Curitiba: Kairós, 2016, p. 39-65.

HELLER, Agnes; FEHÉR, Ferenc. A condição política pós-moderna. Trad. Marcos Santarrita. Rio de Janeiro: Civilização Brasileira, 1998.

JUBILUT, Liliana. O Direito internacional dos refugiados e sua aplicação no orçamento jurídico brasileiro. São Paulo: Método, 2007.

JUDT, Tony. Postwar: A Historty of Europe Since 1945. New York: Penguin Books, 2005.

KAFIR, Khadija; JAMES, Sabatina. Por que minha mãe me quer morta. In Ex-muçulmanos. 1 set. 2015. Disponível em: http://www.exmuculmanos.com/porque-minha-mae-me-quer-morta/ . Acesso em: 12 ago. 2016.

LEHNE, Stefan. The Tempting Trap of Fortress Europe. In Carnegie Europe. Bruxela, 21 abr. 2016. Disponível em: www.carnegieeurope.eu/2016/04/21/temptingtrap-of-fortress-europe/ixdx . Acesso em: 11 ago. 2016.

MOLIN, Carolina. Os direitos humanos dos humanos sem direitos. Refugiados e a política do protesto. In $\mathbf{R e}-$ vista Brasileira de Ciências Sociais, v. 26, n. 76, São Paulo, junho, 2011, p. 145-155. Disponível em: http:// www.redalyc.org/articulo.oa?id=10719120008 . Acesso em: 25 jul. 2016.

MOREIRA, Julia Bertino. Direito Internacional dos Refugiados e a Legislação Brasileira. In RAMINA, Larissa; FRIEDRICH, Tatyana Scheila (Coord). Coleção Direito Internacional Multifacetado: Direitos Humanos, Guerra e Paz. V. III. Curitiba: Juruá, 2014, p.110-111.

OLSEN, Ana Carolina Lopes. Imigração e reconhecimento de direitos: o desafio do Brasil na era da (in) tolerância. Revista de Direito Econômico e Socioambiental, Curitiba, v. 6, n. 2, p. 122-155, jul./dez. 2015. Disponível em: http://dx.doi.org/10.7213/rev. dir.econ.socioambienta.06.002.AO05 . Acesso em 22 jul. 2016.

PAMPLONA, Danielle Anne; PIOVESAN, Flávia. O instituto do refúgio no Brasil: práticas recentes. In Revista de Direitos Fundamentais e Democracia, v. 17, n. 17, Curitiba: janeiro/junho de 2015, p. 43-55.

PIOVESAN, Flávia. Direitos Humanos e Justiça Internacional. 6 ed. São Paulo: Saraiva, 2015.

\section{Direitos Humanos e o Direito Con-}

stitucional Internacional. 13 ed. São Paulo: Saraiva, 2012.

Refugiados sob a Perspectiva dos Direitos Humanos. In: Seminário Internacional "Fronteiras em Movimento: Deslocamentos e outras Dimensões do Vivido", Diversitas - Núcleo de Estudos das Diversidades, Intolerâncias e Conflitos, Universidade de São Paulo, São Paulo: 2013.

PITA, Agni Castro. Direitos Humanos e Direito Internacional dos Refugiados. In GEDIEL, José Antônio Peres; GODOY, Gabriel Gualano de. (Org.) Refúgio e Hospitalidade. Curitiba: Kairós, 2016, p. 5-16.

RORTY, Richard. Contingência, Ironia e Solidariedade. Trad. Vera Ribeiro. São Paulo: Martins Fontes, 2007.

SANDEL, Michael. Justiça: O que é fazer a coisa certa. 15 ed. Rio de Janeiro: Civilização Brasileira, 2014.

SILVA, Sérgio Gomes da. Direitos humanos: entre o princípio de igualdade e a tolerância. In Revista Praia Vermelha, v. 19, n. 1. Rio de Janeiro, jan-jul 2010.

TOMASKY, Michael. Can the Monster be Elected? In The New York Review of Books. V. LXIII, n. 12, New York: jul-ago 2016. 
Turquia suspende aplicação da Convenção Europeia dos Direitos Humanos. O Globo. 21 jul. 2016. Disponível em: http://oglobo.globo.com/mundo/turquia-suspende-aplicacao-da-convencao-europeia-dos-direitos-humanos-19757361\#ixzz4H35ys1zT . Acesso em: 11 ago. 2016.

WACHOWICZ, Marcos. O direito de asilo como expressão dos direitos humanos. In Revista da Faculdade de Direito da Universidade Federal do Paraná. Curitiba: UFPR, 2002. Disponível em: www.revistas. ufpr.br/direito/article/download/1776/1473 . Acesso em 07 ago. 2016, p. 143-156.

WALZER, Michael. Da Tolerância. Trad. Almiro Pisetta. São Paulo: Martins Fontes, 1999.
Esferas da Justiça: Uma defesa do pluralismo e da igualdade. Trad. Jussara Simões. São Paulo: Martins Fontes, 2003

WOLFF, Robert Paul. Além da Tolerância. In WOLFF, Robert Paul; MOORE JR., Barrington; MARCUSE, Herbert. Crítica da Tolerância Pura. Trad. Ruy Jungmann. Rio de Janeiro: Zahar, 1970

ZIZEK, Slavoj. In the Wake of Paris Attacks the Left Must Embrace Its Radical Western Roots. In These Times. 16 nov. 2015. Disponível em: http://inthesetimes.com/article/ print/18605/breaking-the-taboos-in-the-wake-of-paris-attacks-the-left-must-embrace . Acesso em 08 ago. 2016. 
Para publicar na Revista de Direito Internacional, acesse o endereço eletrônico www.rdi.uniceub.br ou www.brazilianjournal.org.

Observe as normas de publicação, para facilitar e agilizar o trabalho de edição. 